مجلة كلية الآداب، جامعة سوهاج، العدد الثالث والخمسون، الجزء الثاني، أكتوبر 19 ـ ب م

تعرض الأطفال العرب القنـوات الأطفال المتخصصة و علاقته بـالو عي الصصي

لديهم مصر والجزائر نموذفًا

سوسن عفيفي خالا أبوزيد (*) سووديا

مقدمة الدراستة:

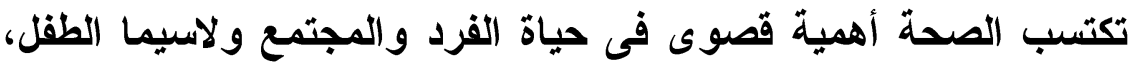

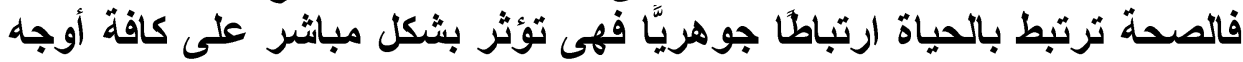

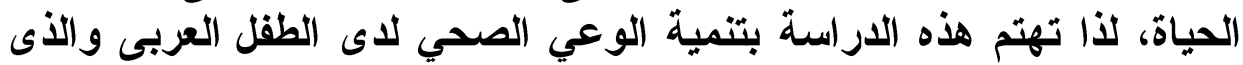

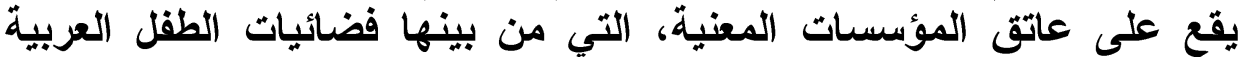

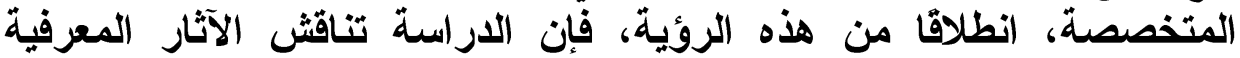

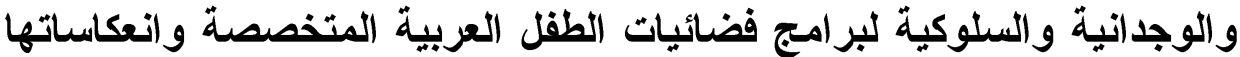
في تنمية الوعي الصحي للطفل لاسيما في مرحلة الطفولة المئلة المتأخرة

\title{
الدراسات السابقةة:
}

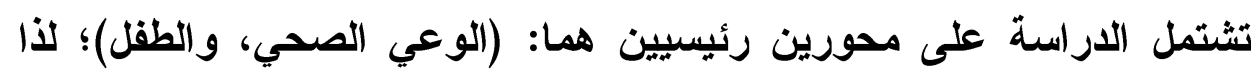

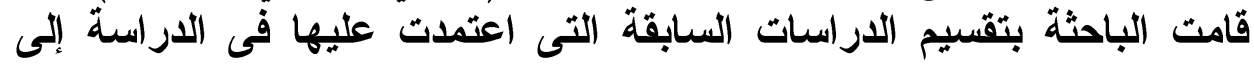
محورين رئيسيين هى: المحور الأول: الارئات هئ التي تناولت دور وسائل الإعلام ولاسيما القنوات الفضائية في تنمية الورعي الصوري. الصحي.

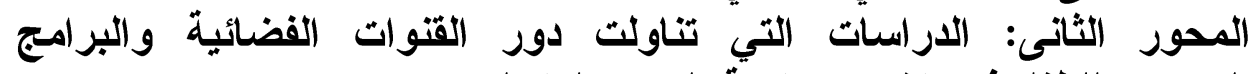
الموجهه للطفل فى تنشئته وتنمية الوعي الوعي العام لايه. وذلاك على النحو التالى في

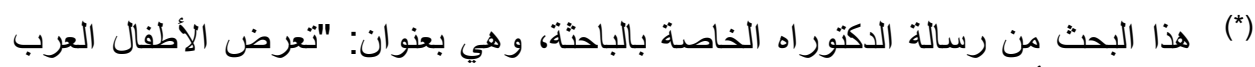

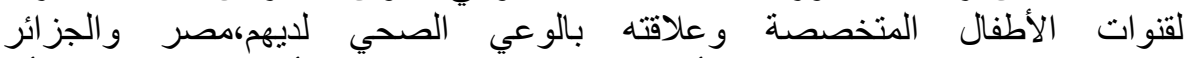

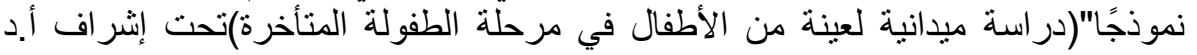

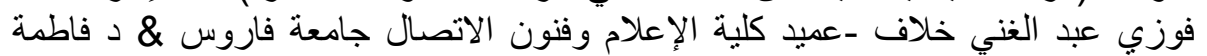
الز هر اء صالح أحمد- الأستاذ المساعد بقسم الإعلام بكلية الآداب جامعة سوهاج. 
المجور الأول: الدراسات التي تناولت دور وسائل الإعلام ولاسيما القنوات الفضائية في تنمية الوعي الصدي.

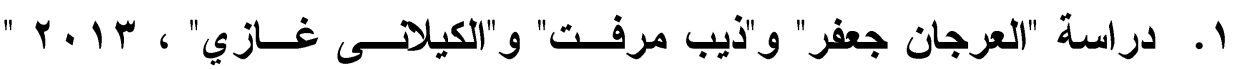

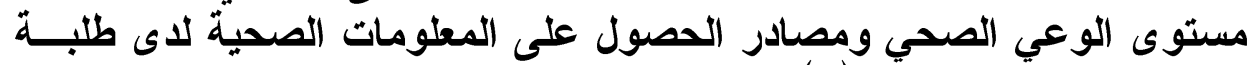

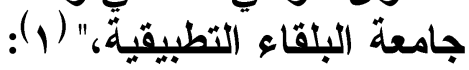
تهلف هذه الاراسة إلى التعرف على مستوى الته الوعي الصحي ومصادر الحصول

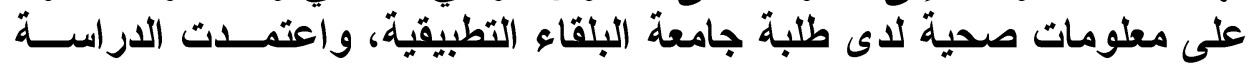

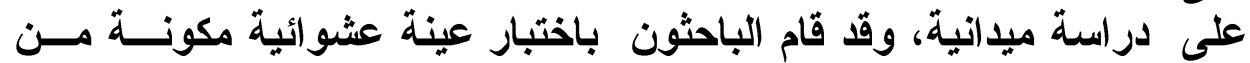

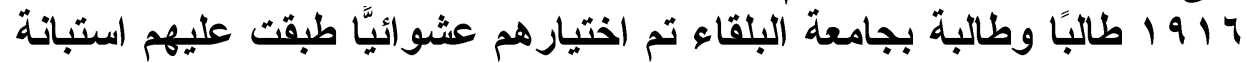

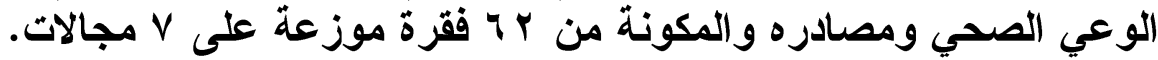

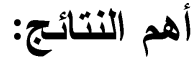

- مستوى الوعي الصحي جاء مرتفعًا بنسبة مئوية للاســتجابة هـ ــ 9 بينـــ

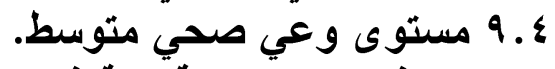
- وجود فروق إحصائية دالة في مستوى الوعي الصحي بين الإناث والـــكور

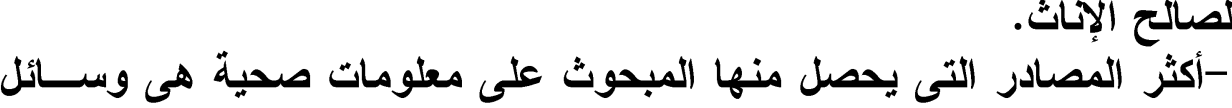

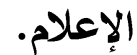
* الاعتفادت الباحثة فى التعرف على مصادر الوعي الصحي.

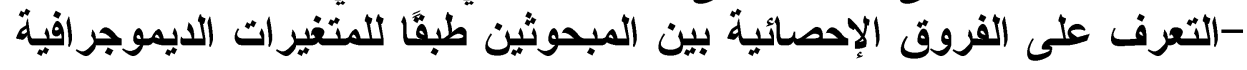
ومستوى الوعي الصحي لايهم.

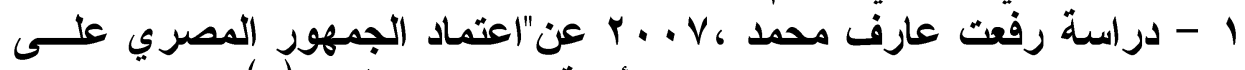

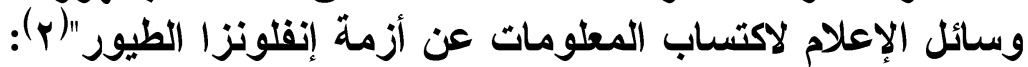

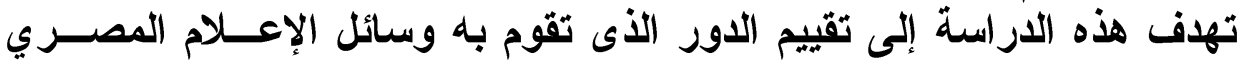

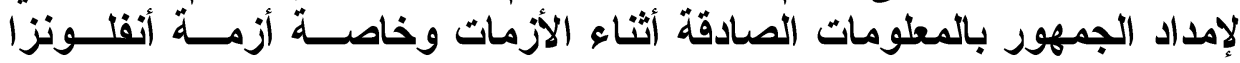

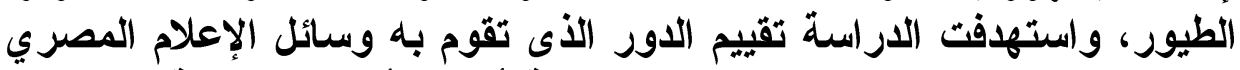

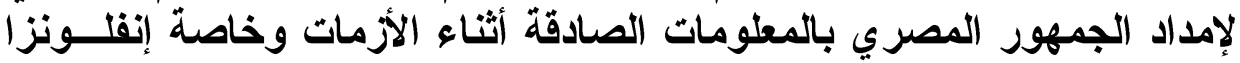

( (العرجان جعفر وذيب مرفت و الكيلانى غازى مستوى الوعي الصحي ومصادر الحصول

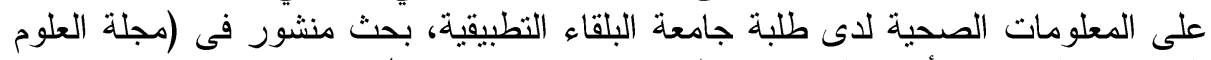

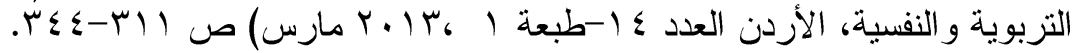

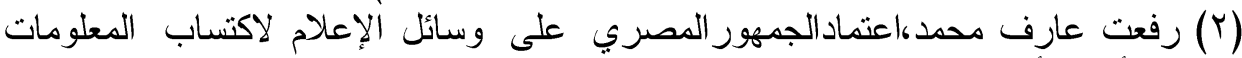
عن أزمة أنفلونزا الطيور (المجلة الكصرية لبحوث الإعلام ،العدد الثامن والعشرون . ( r... $v_{6}$ 
مجلة كلية الآداب، جامعة سوهاج، العدد الثالث والخمسون، الجزء الثاني، أكتوبر 19 • ب م

الطيور وهى دراسة وصفية تحليلية تكونت من . V مفردة، ومن نتائج هـــه

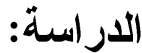

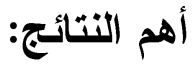

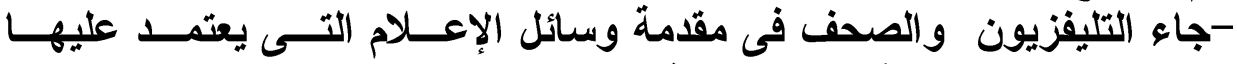

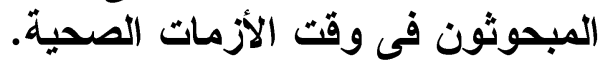

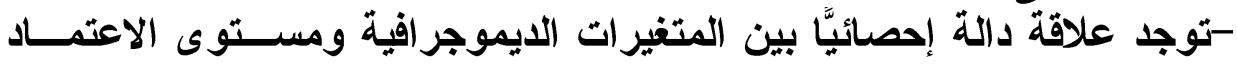

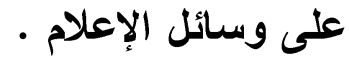

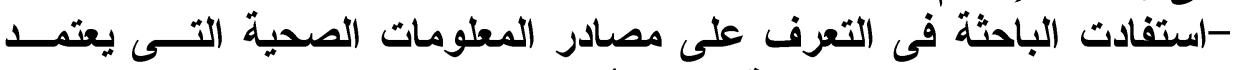
عليها الجمهور المصري خاصة وقة فلت الأزمات.

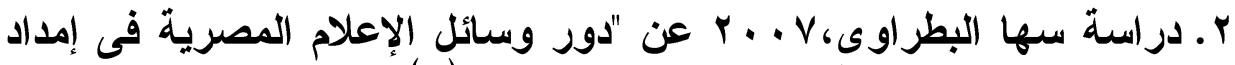

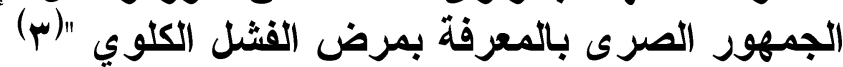

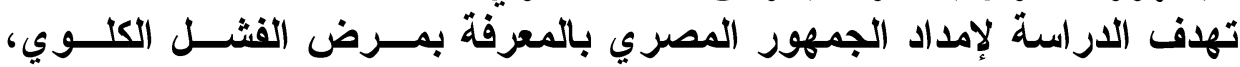

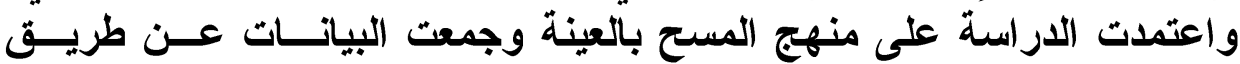

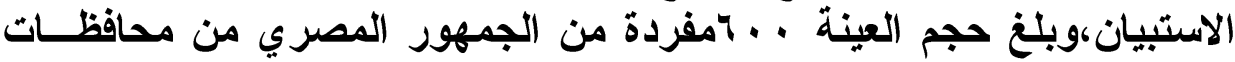
القاهرة الكبرى والشرقية والصعيد.

ومن نتائج هذه الار اسة:

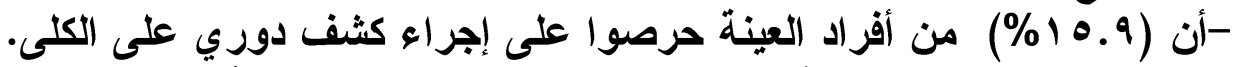

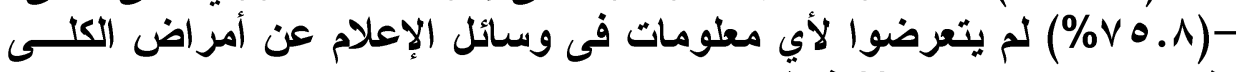

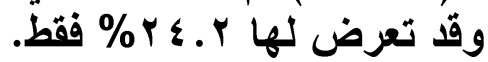

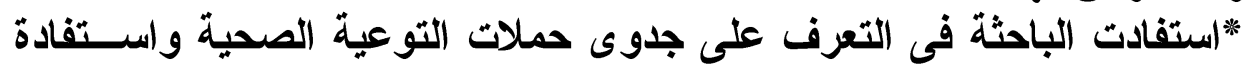

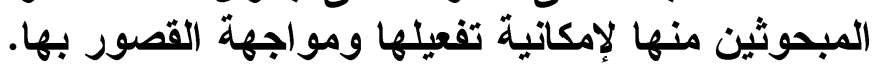

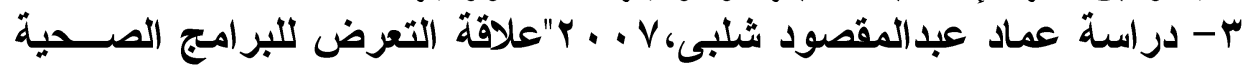

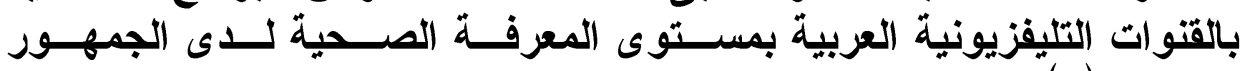
"المصري" (ع ع)": تهدف هذه الاراسة إلى معرفة مدى اعتى العـاد الجمهور فى المجتمــع المصــري

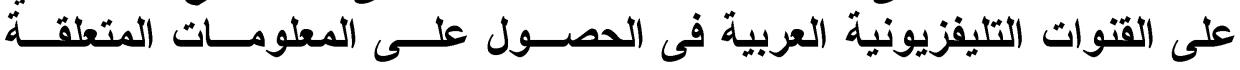

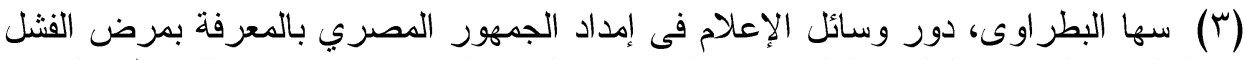

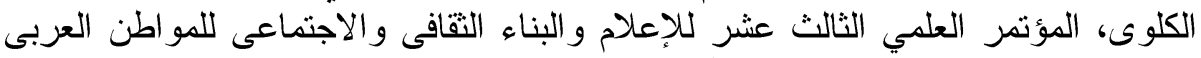

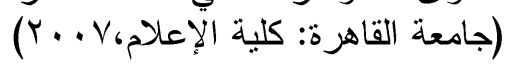

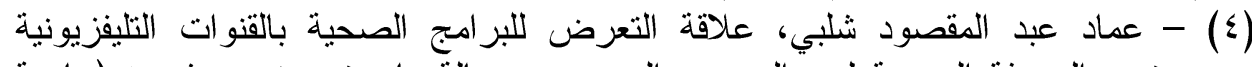
بمستوى المعرفة الصحية لدى الجمهور المصري، رسالة ماجستير غير منشورة (جامعة النية

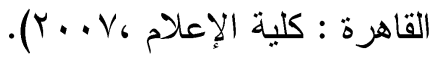




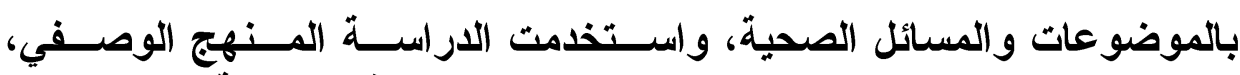

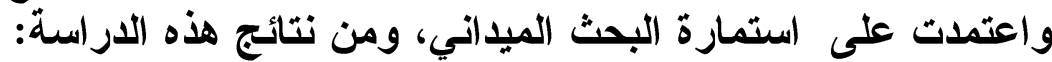

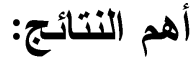

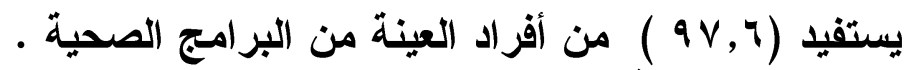

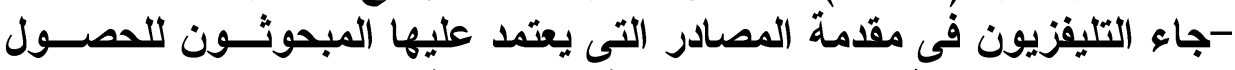

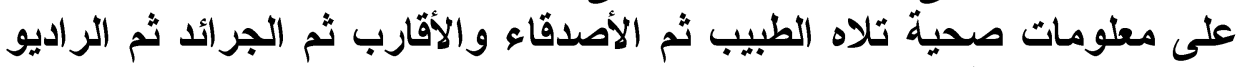

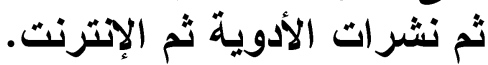

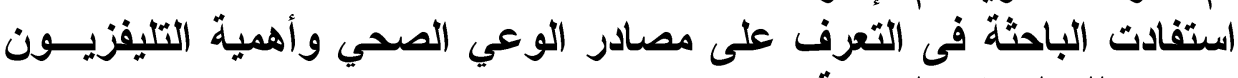
كمصدر للمعلومات الصحية. §- در اسدة 2006،Viswanath عن "التعرض لوسيائل الاتصال ومستوى معرفة

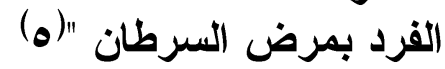

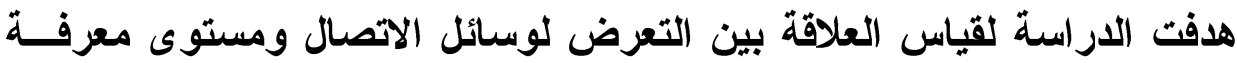

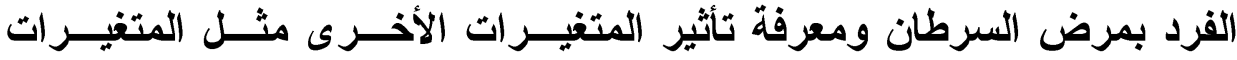

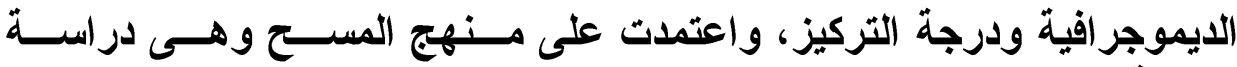

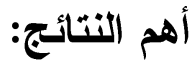

- كلما ارتفع المستوى الاجتماعى والاقتصــادى ارتفــع مســتوى المعرفــة

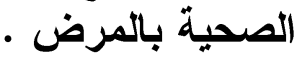

- زيادة تدفق المعلومات ساعد على تضييق الفجوة المعرفية .

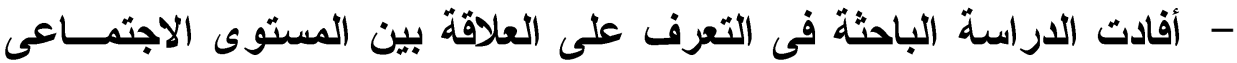
والاقتصادى وارتفاع مستوى المعرفة الصنة فئة الصحية.

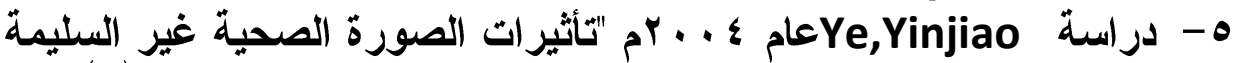

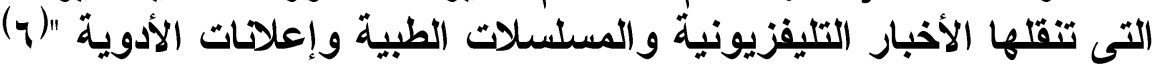

\section{5)Viswanath.V.Breen.H.Moser.P.Richard} .Bstede.W.Randoliph and R.william,cancer and disparities in the information age : (Journal Of Healthcommunication, Vol .11,No 2006) pp1-19.

6)Ye,Yinjiao."The role of Media health information in individuals'Subjective Well -Being :An Exploration of the effects of portrayals of health risks in television News. Medical drams,and pharmaceutical advertising "Ph.D. USA:the university, Of Alabma,2004) 
هدفت الاراسة للتعزف على دور المعلومات الصـــية فــى وســائل الإعـلام

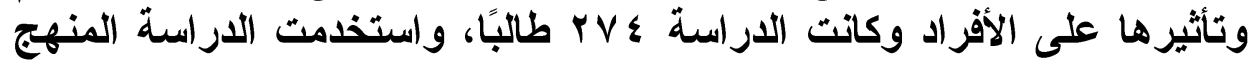
الوصفي، واعتمدث على استمارة البحث الميداني.

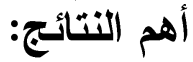

التعرض لأنواع مختلفة من البرامج الصحية التليفزيونيــة شـــيد

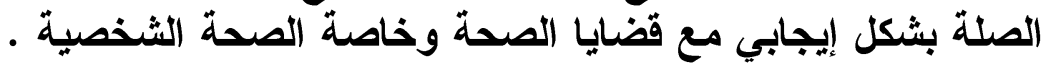

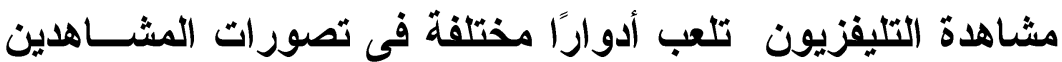
من خلال الواقع الاجتماعى والرضا عن الحياة.

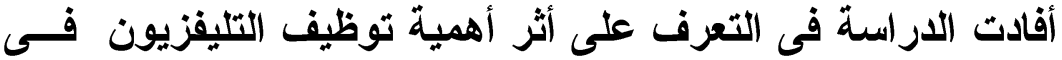

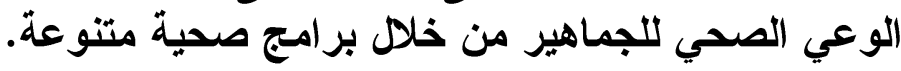

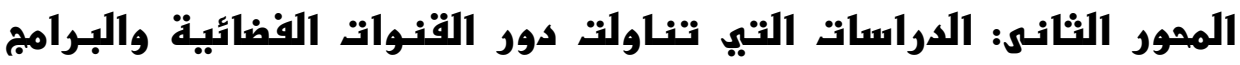
الموجهه للطفل فه تنـشئته وتنـمية الو عي العام لديه. على تنشئة الطفل" (V)

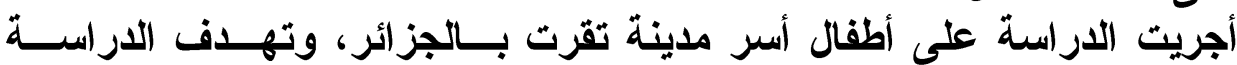

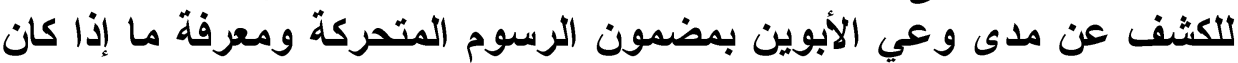

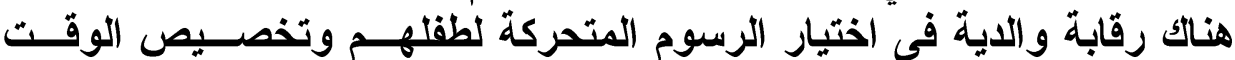

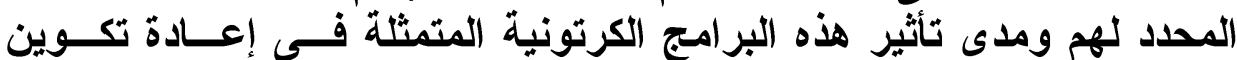

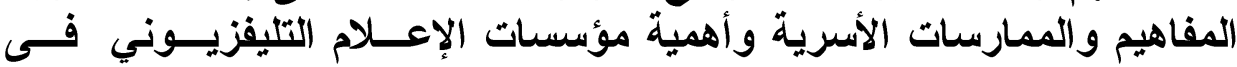

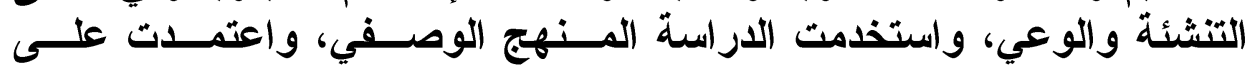
استمارة البحث الميدة واني. ومن نتائج هذه الأدة المئة:

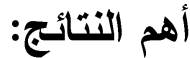
-أن (VT\% ) من أفر اد العينة أجابوا بأنهم يستفيدون من القتوات الفضــائية فى تنمية معارف أطفالأهم.

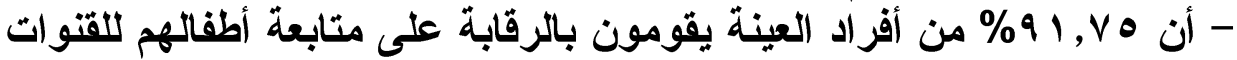
الفضائية . أن

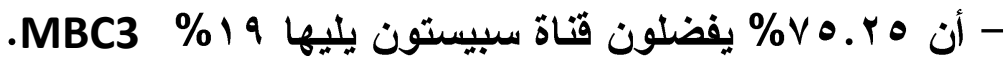

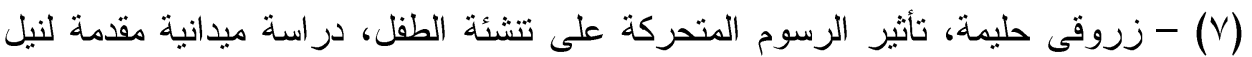

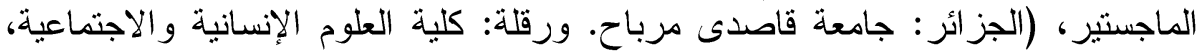




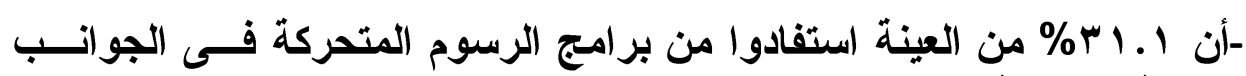

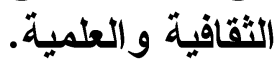
استفادت الباحثة: فى التعرف على مدى أهمية مشاهدة أفلام الكارتون وبرامج

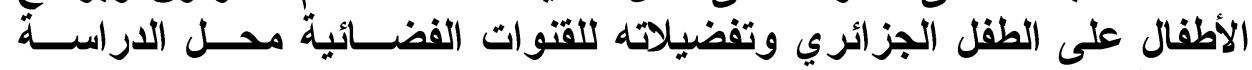

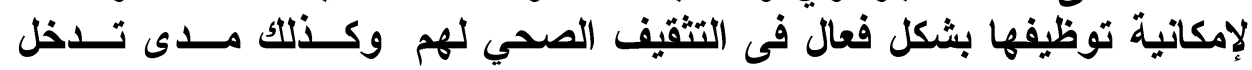
الأسرة لاختيار المحتوى المناسب للطفل فئل ومتابعته.

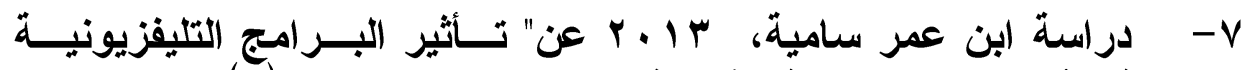

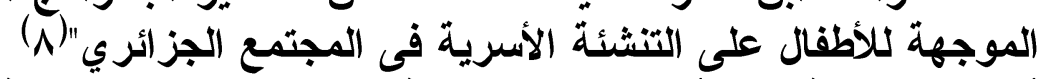

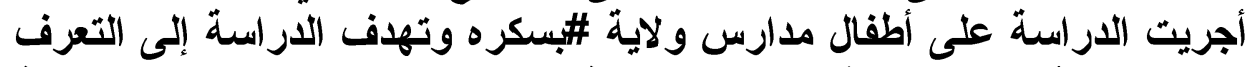

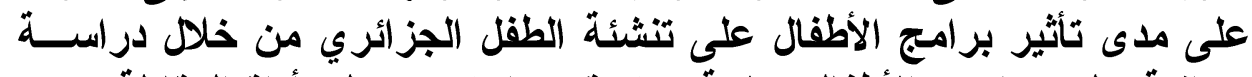

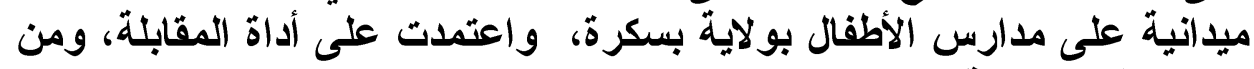
نتائج هذه الارساسة:

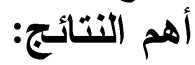

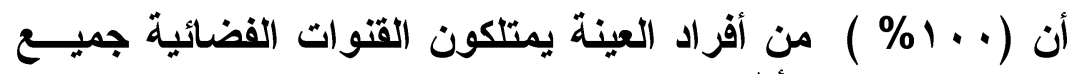
المبحوثين يثاهدون برامج الأطفال.

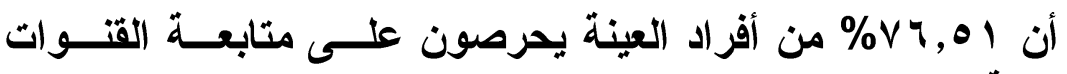

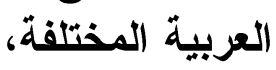

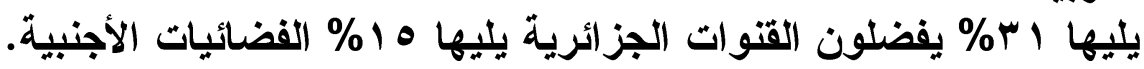

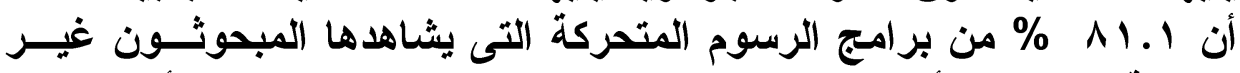

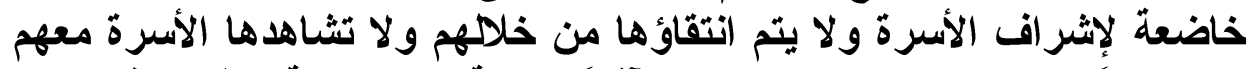

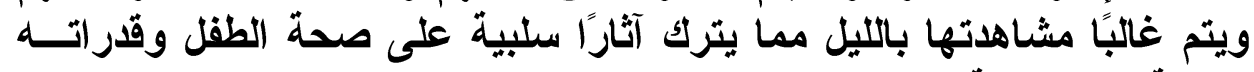

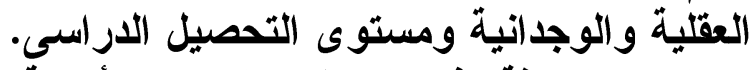

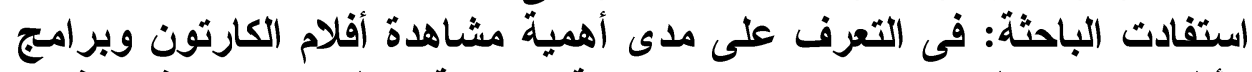

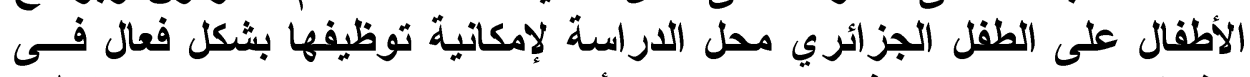
التثقيف الصحي لهم وكذلك مدى تدخل الأسرة لاختيار المحتوى المناسب للتفل للطقل

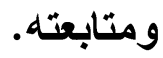

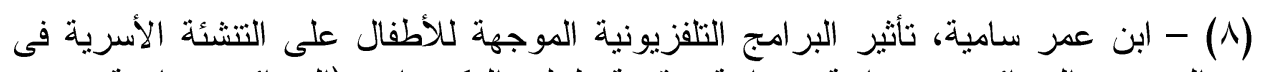

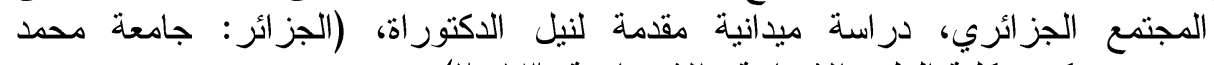

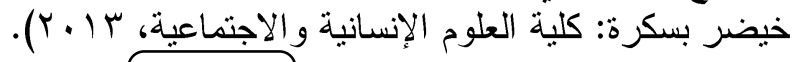




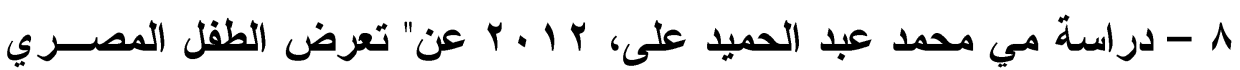

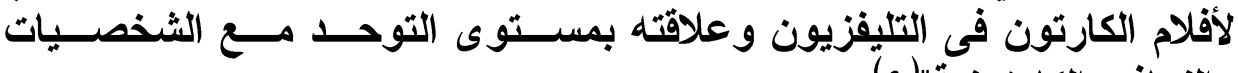

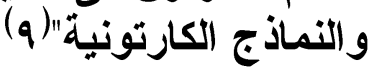

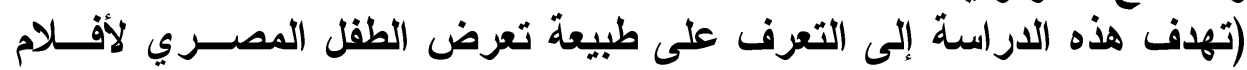

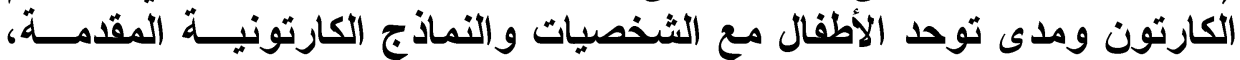

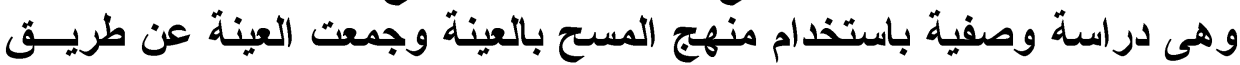

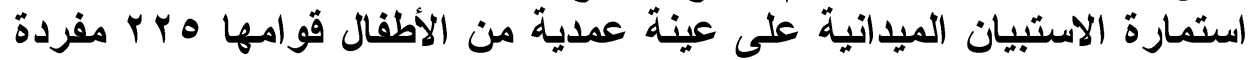

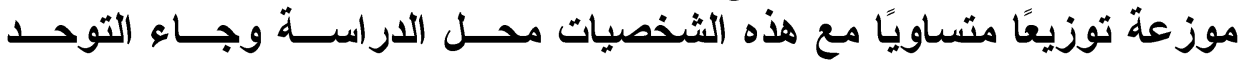

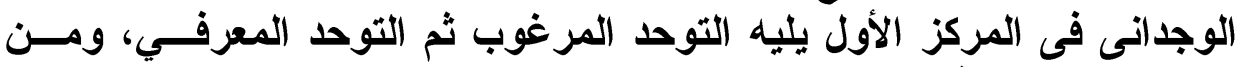

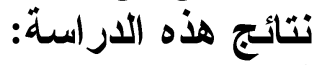

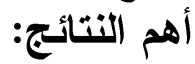

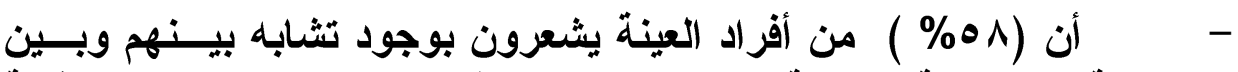

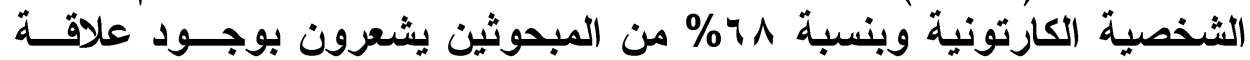
صداقة بينهم وبين الشخصية.

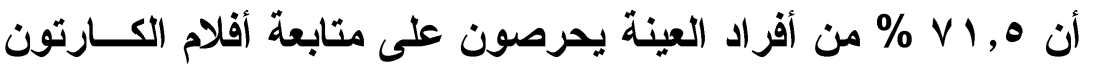
استفادت الباحثة: في التعرف على مدى تأثير مشاهدة أفلام الكـــارتون علــى الإنى

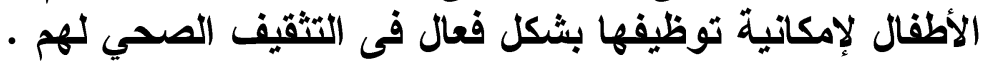

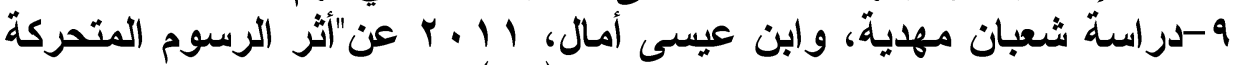

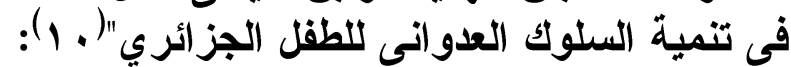

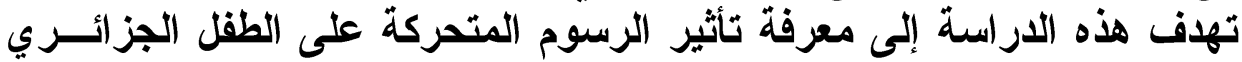

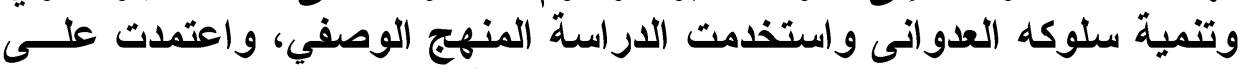

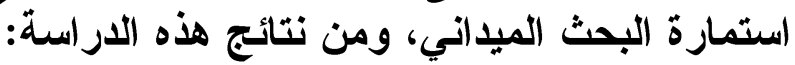

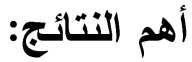
غلب المبحوثين يفضلون الرسوم المتحركة التى فيها حركة وعنـف

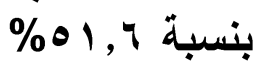

(9) - مي محمد عبد الحميد علي، تعرض الطفل المصري لأفلام الكارتون فى التلفزيون

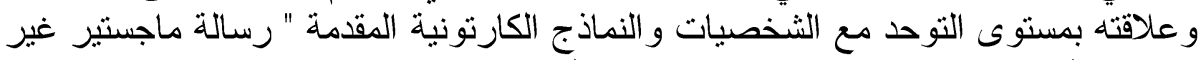

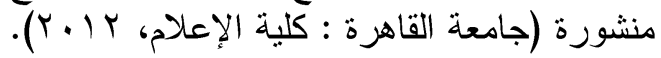

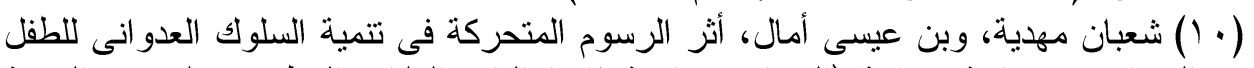

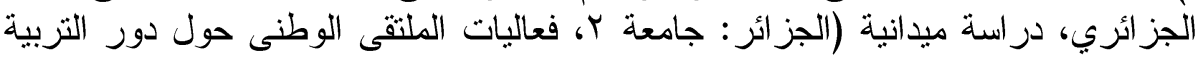

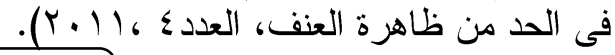
rra 


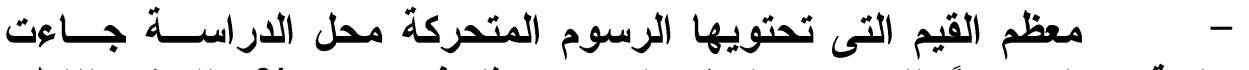

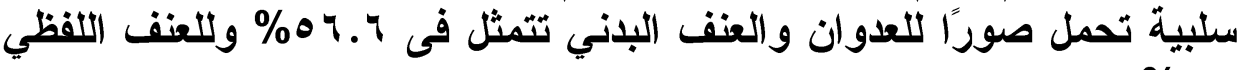
. \% \&

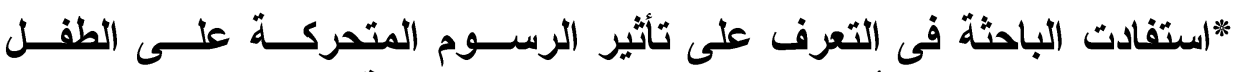

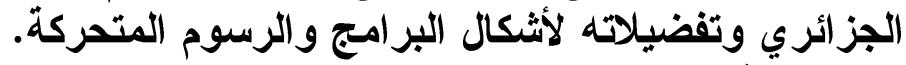

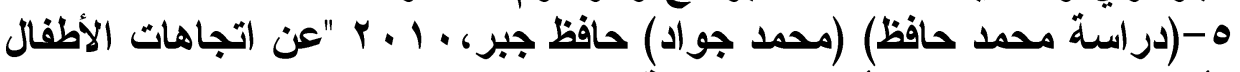

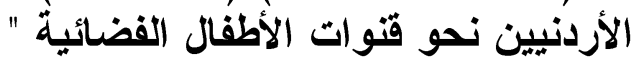

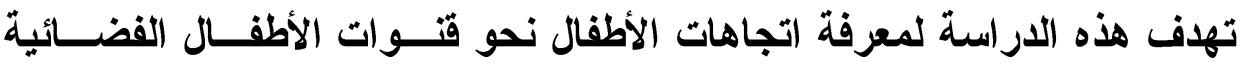

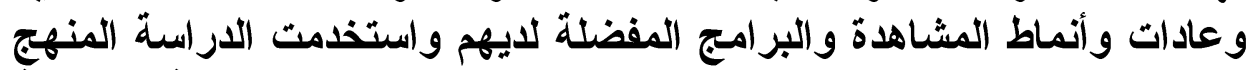
الوصفي، واعتمدت على استمارة البحث الميداني وطبقت على واطنى عينة عشوائية

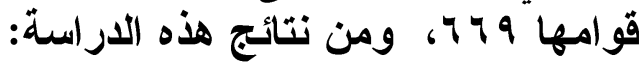

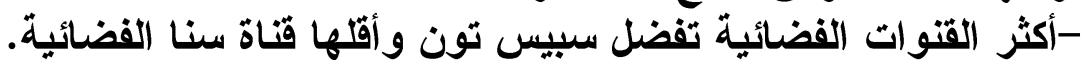

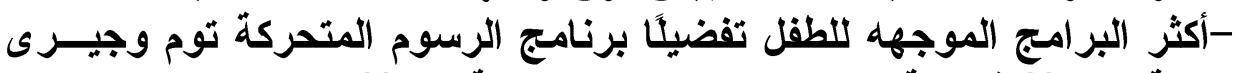

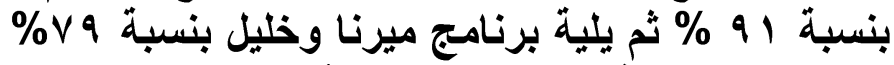

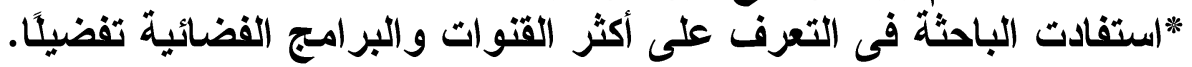

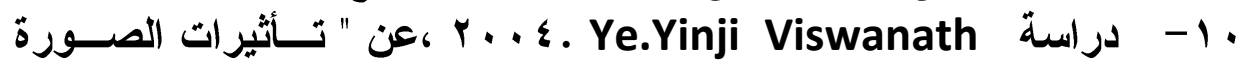

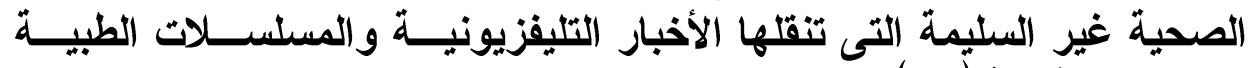

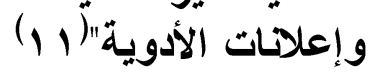

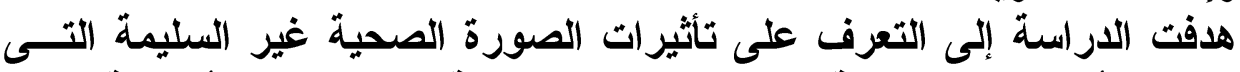

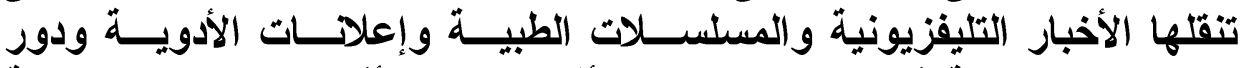

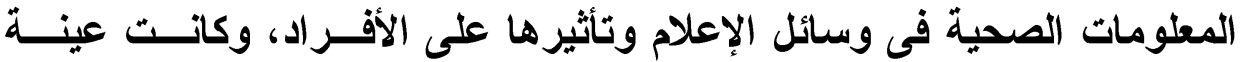

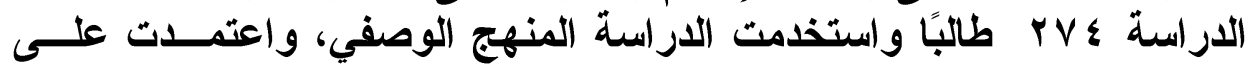
استمارة البحث الميداني.

تعليةز عام على الدراسات السابقةه: ما تضيفه الار اسة إلى الدار الدات الدات السابقة:

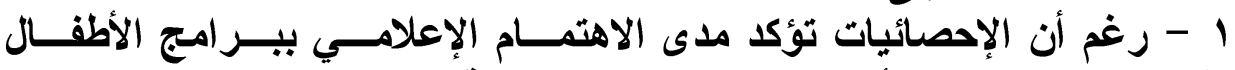

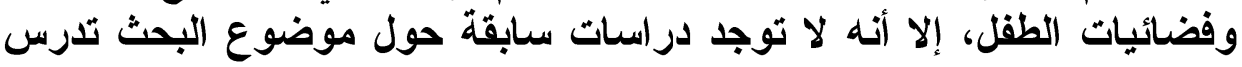

11) Ye.Yinji Viswanath,v.breen,H.Moser,P.Richard,B.Stede,w.Randdolph. and R.William ao" The role of media health information in individuals subjective well-Being:an Explloration of effects of portrayals of health risk in television news .medical dramas, and pharmaceutical advertising Ph.D (usa :the university of Albama,2004) 
العلاقة بين الاعتماد على فضائيات الطقل المتخصصة وبين مســتوى الــوعي ولئي

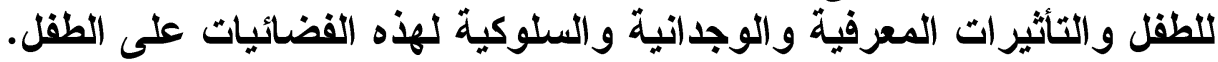

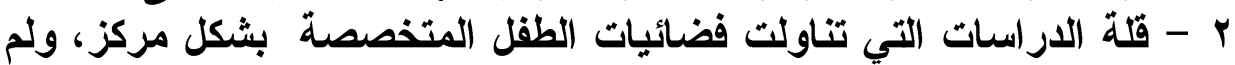

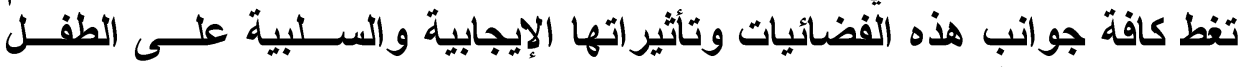

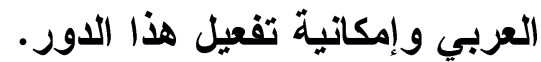

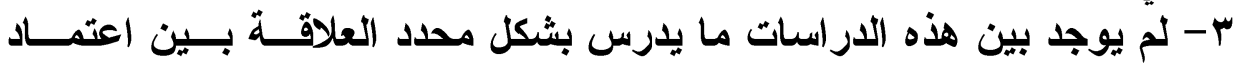

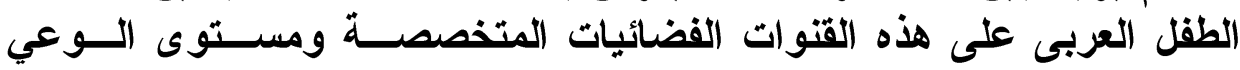

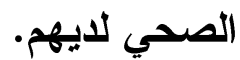

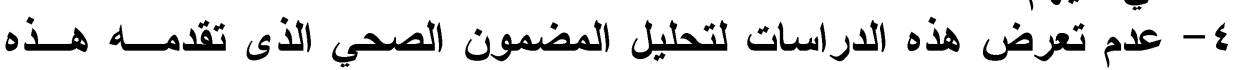
الفضائيات من خلام نعل بر امجها للطفل.

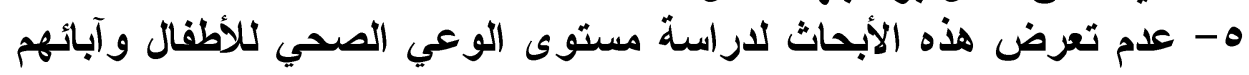
ومصادره لادى كليهما. أفادت الار استات السابقة البهائة الباحثة فيما يلي:

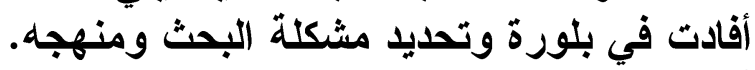

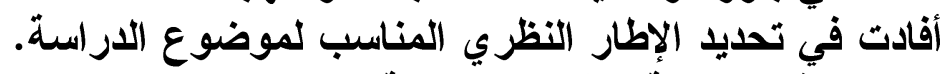

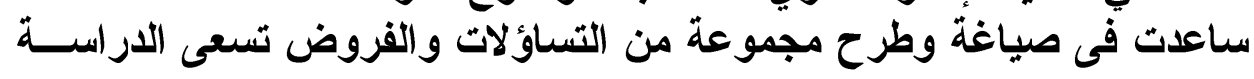
إلى اختبارها. التعرف على التأثيرات المعرفية والوجداتية والسلوكية الناتجــة عــن عمليــة الاعتماد

\section{مشكالة الدراسةة:}

نحن بحاجة لتأسيس إعلام مرئي قوي لطفل قائم على مبادئ إعلامية

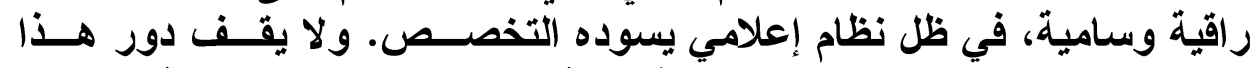

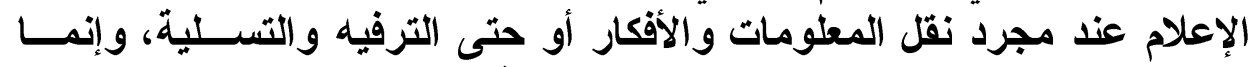

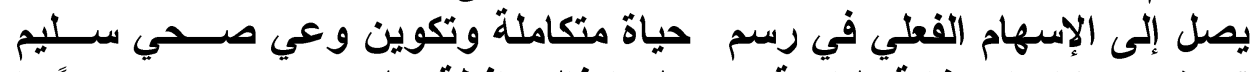

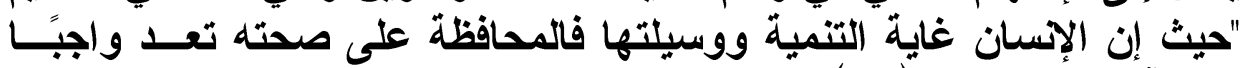

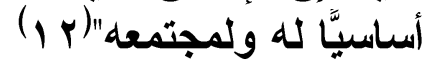

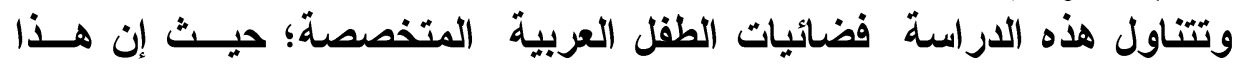

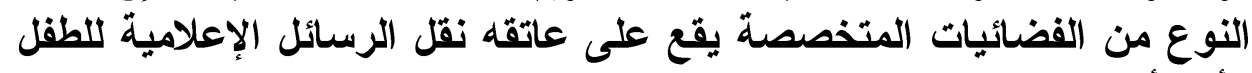
وأحد أهم مصادر تكوين الوعي لايله.

(Y (Y) هويدا محمود الأتربي، الربية الصحية فى مرحلة التعليم الأساسي بين الواقع والممكن،

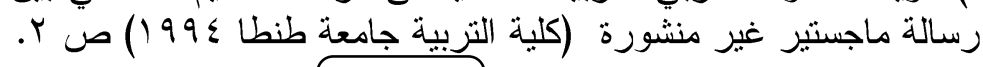




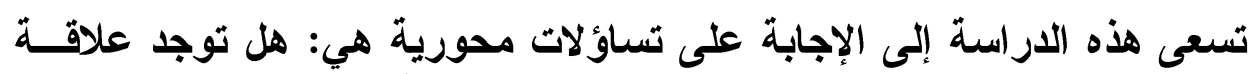

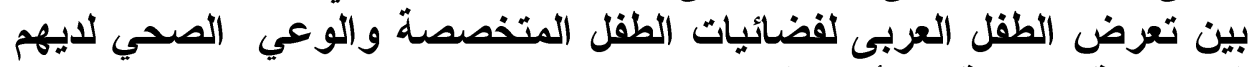

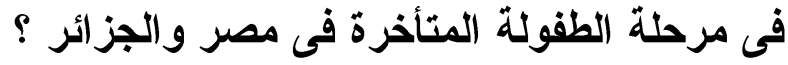

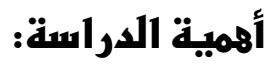

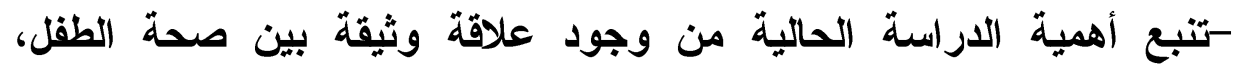

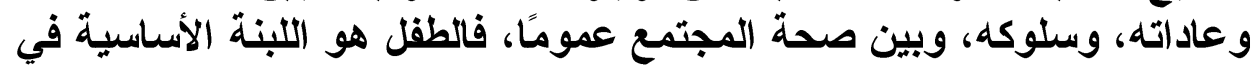

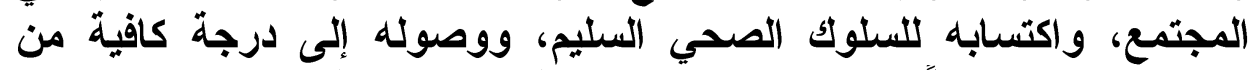

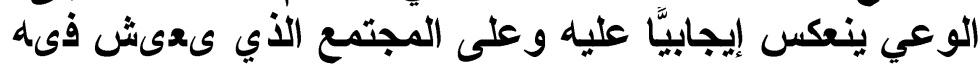

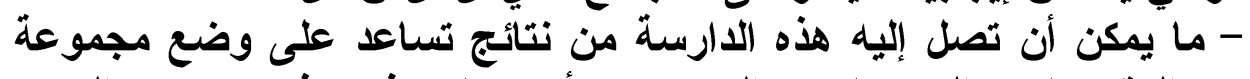

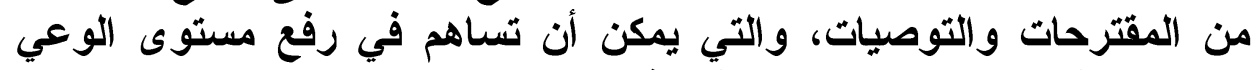

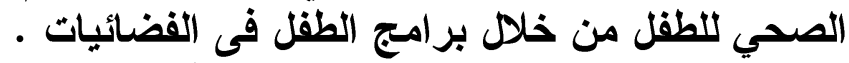

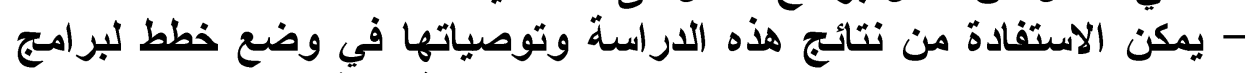

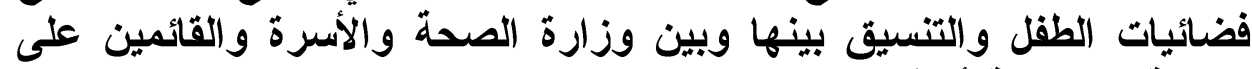
الصحة المدرسية أيضًا.

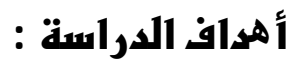

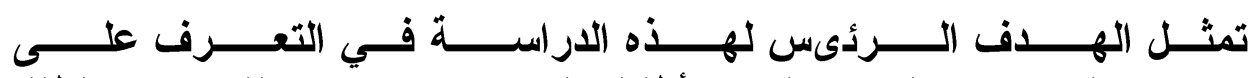

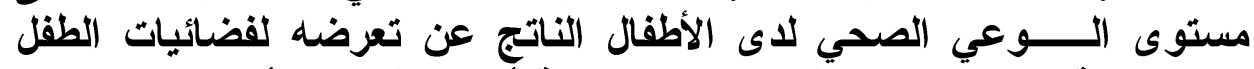

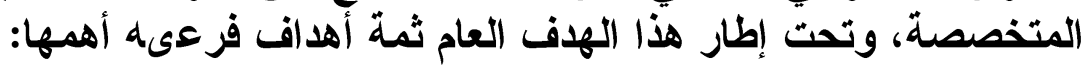

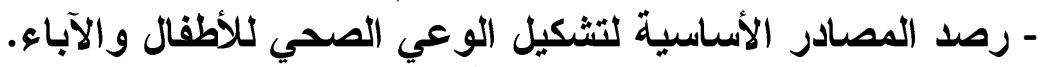

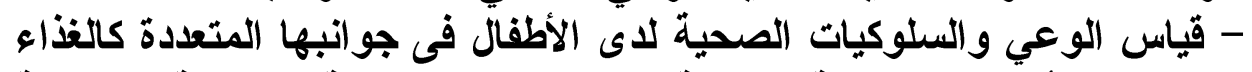

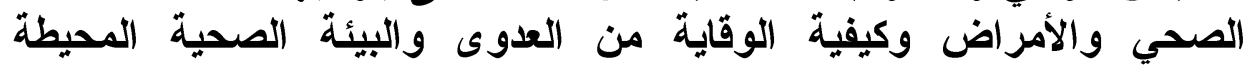
وغيرها من جوانب الوعي الصحئ الصحي.

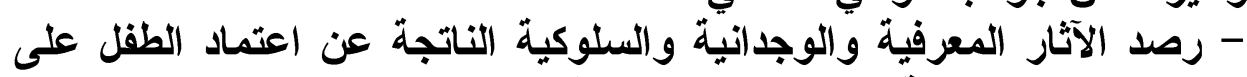

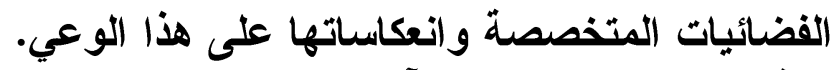
- قياس الوعي الصحي للآباء. - التعرف على برامي المئئ لأطفال التى تقدم معلومات ومعارف صحية. - رصد المشكلات الصحية المنتشرة بين الأطفال

فروض الدراسة وتساؤلاتها:

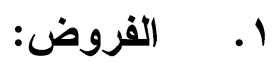

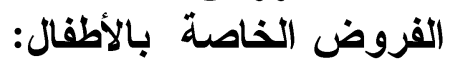

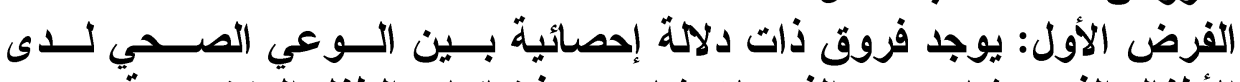
الأطفال الذين يثاهدون والأين لا يشاهدون فضائيات الطفل المتخصصة. 


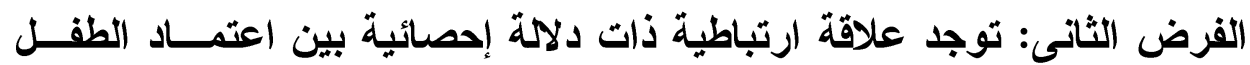

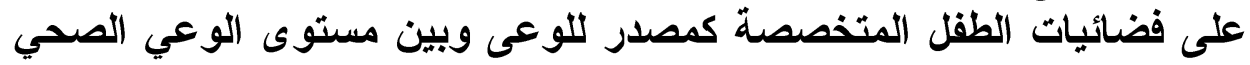
لايه. القرض الثالث: توجد فروق ذات دلامة إحصائية بين مستوى الوعي الصــحي

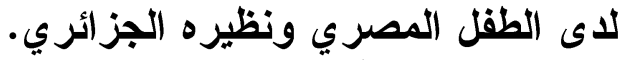
الفروض الخاصة بالآباء

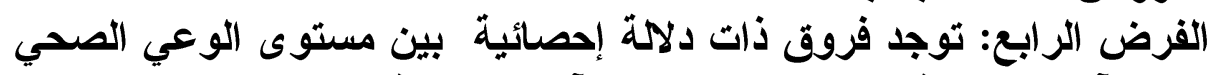

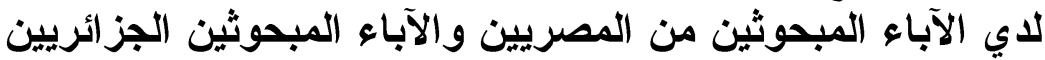

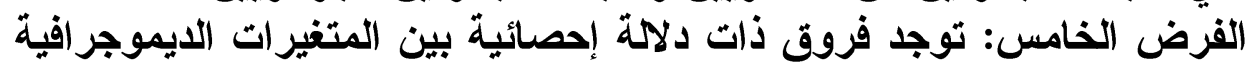

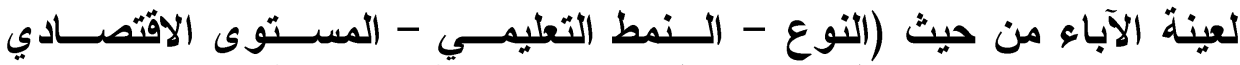

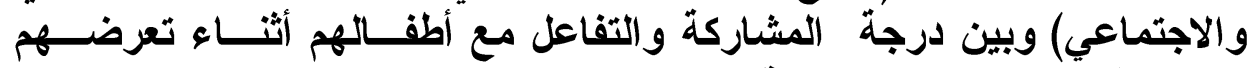
لبرامج فضائيات الطفل وبن الصحية.

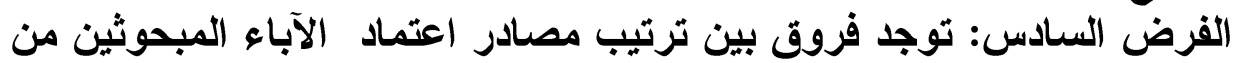

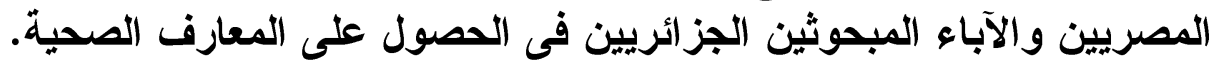
تصياؤلات الدرا11نة:

تسعى الار استة إلى تحقيق عدة أهداف يمكن بلورتها من خلادل الإجابــة علـى التساؤلات الآتية: التئي ا. ـ ماهو معدل مشاهدة المبحوثين من الأطفال لفضائيات الطفل المتخصصــة

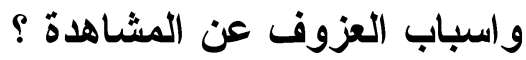

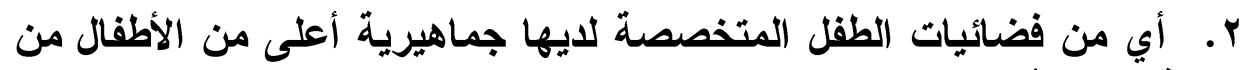
وجهة نظر الأطفال؟ في أبات r. أي من فضائيات الطفل المتخصصة لايها جماهيرية أعلى من الأطفال من وجهة نظر الأباء؟ هن فئيات ع. - هل يختار الطفل برامجه بنفسه أم بمساعدة الآخرين من وجهة نظهـر الأطفال المبحوثين وآبائهم؟ هلئار الطئ ه. ماهى مصادر الأطفال والأباء فى الحصول المصول على المعلومات الصحية ؟

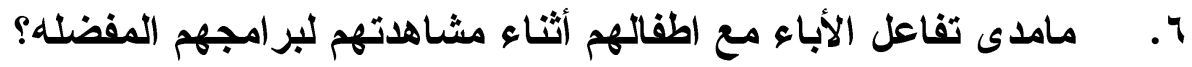

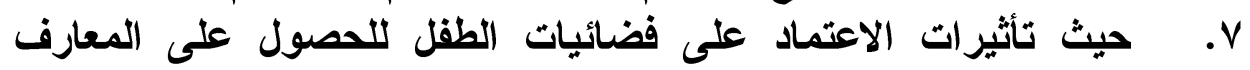
والوعي الصحي ^. ماً أكثر السلبيات التي يراها الأطفال والآباء فى برامج هذه القنوات فـى تقديمها للمعارف صحية ألئب

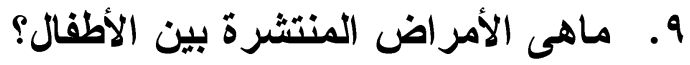




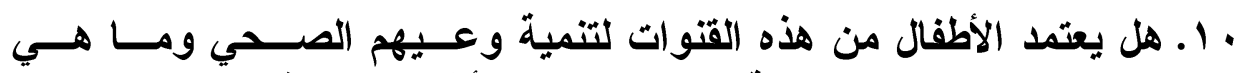

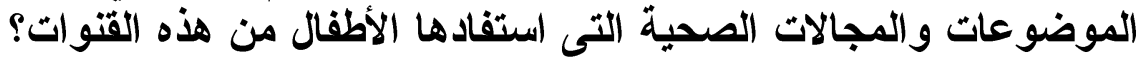

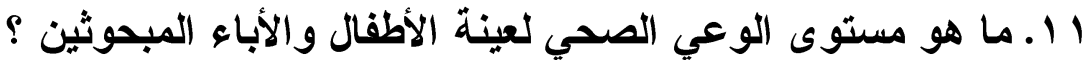

1الإطار النظربي للدراسةة:

\section{نظرية الدراسة (نظربة الاعتماد على وسائل الإعلام):}

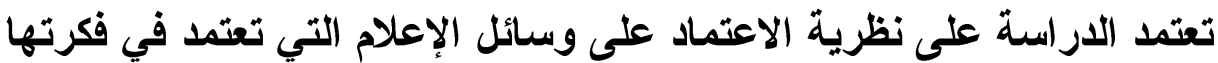

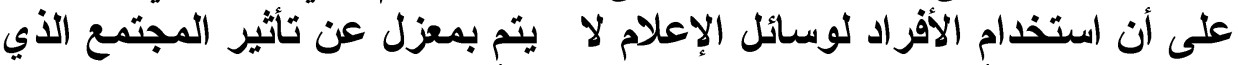

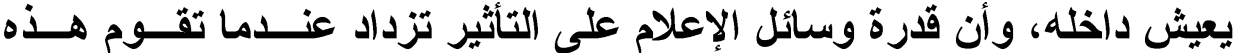

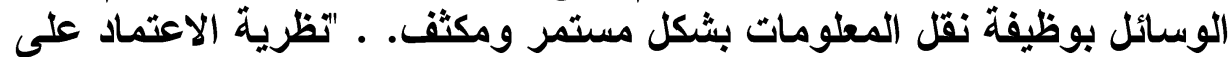

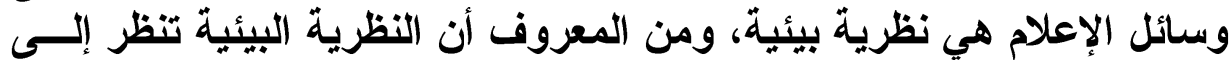

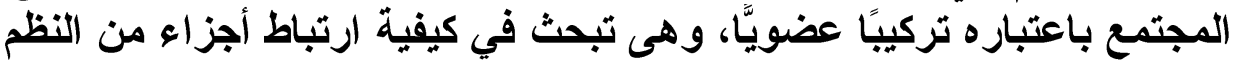

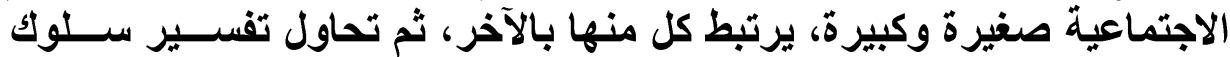

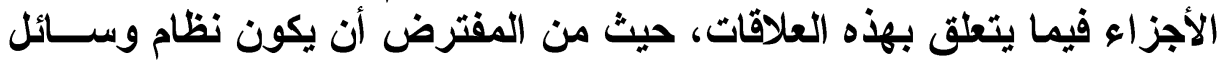

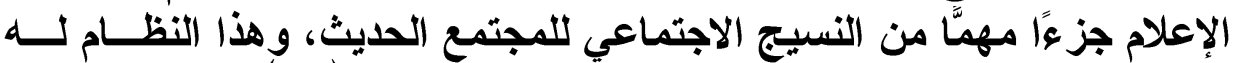

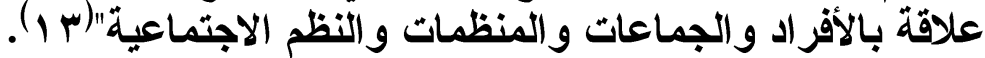

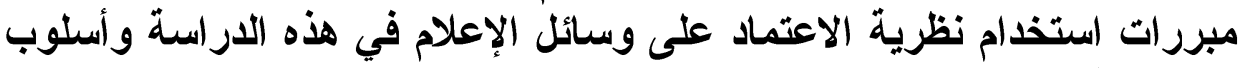
تطبيقها في البحث الميداني:

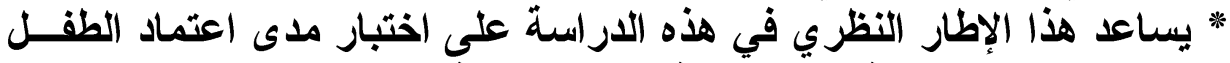

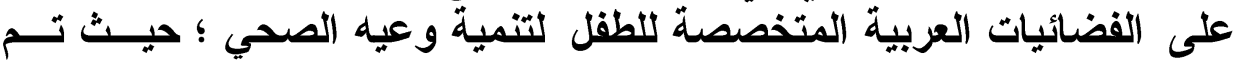

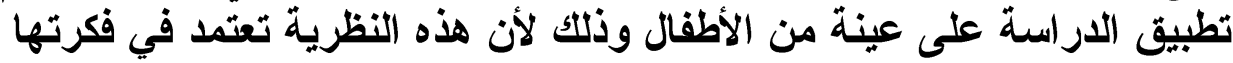

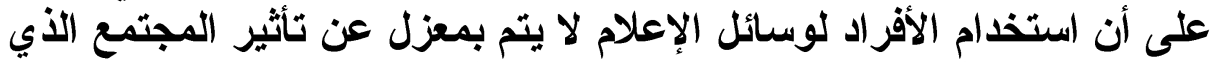

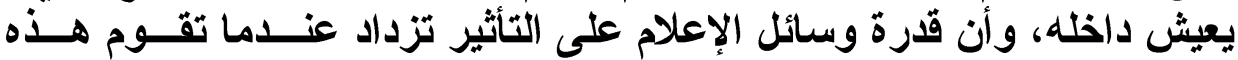

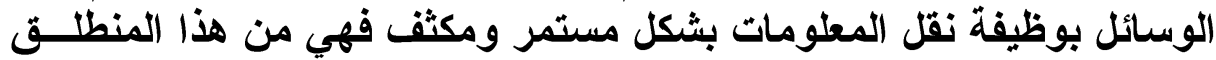

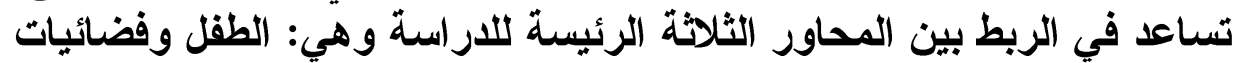

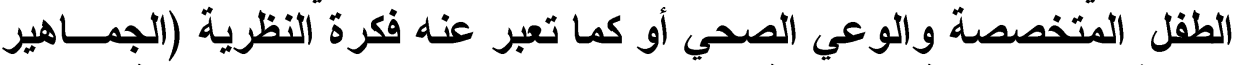

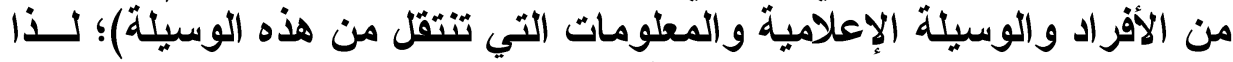

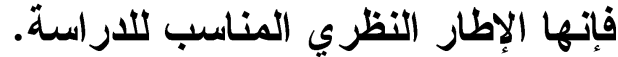
وتحتاج الباحثة في دراستها للوعي الصحي -الناتج عن الاعتماد علــى هــــه

13 ) Sandra ball. Rokeach :the Origins of Individual Media system dependency,Asocial Framework, communication research,(vol.12,no.4,October 1985)pp.485-488 


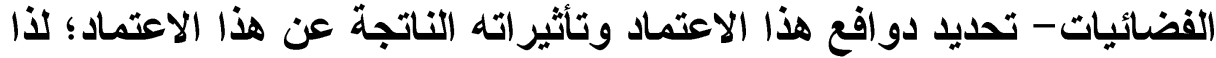

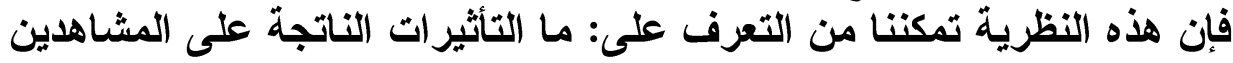

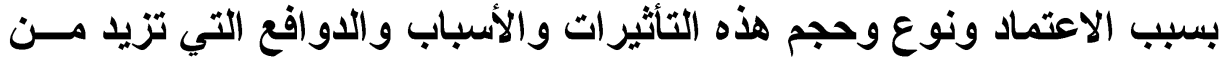

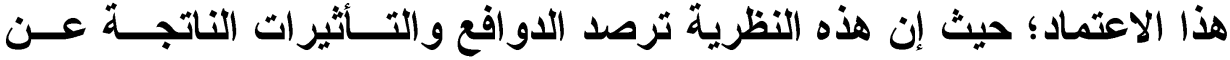

الاعتماد.

\section{نو عم الدراسة ومنـهجما:}

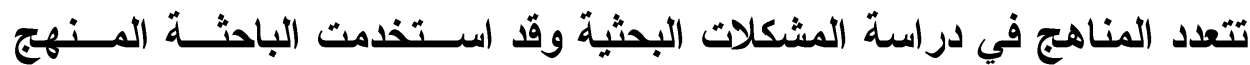

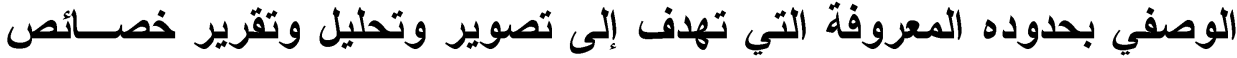
الظو اهز .

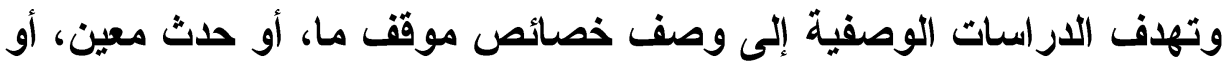

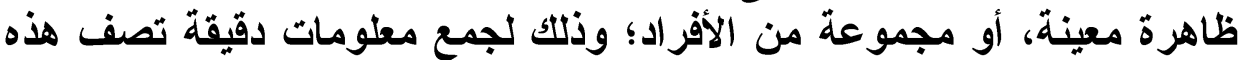

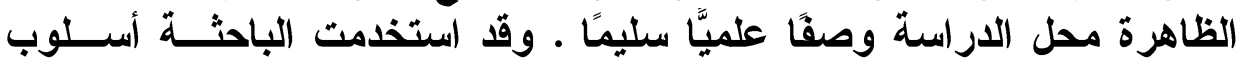

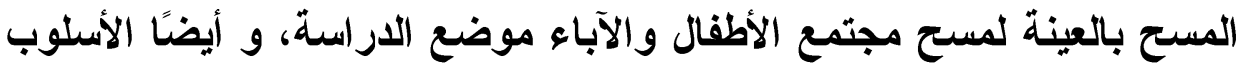
الإحصائي للتحليل الكمي للبيانات.

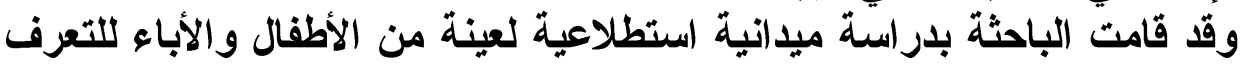

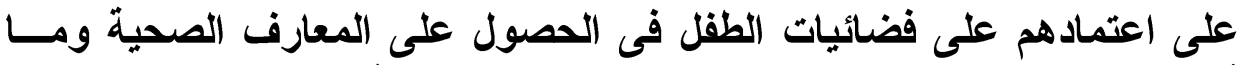

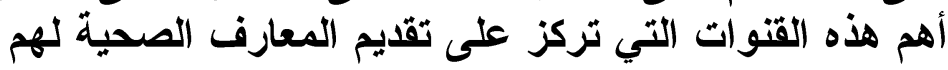
r مجتمع الدراسة:

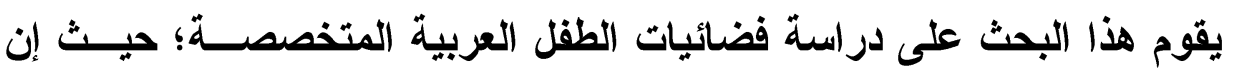

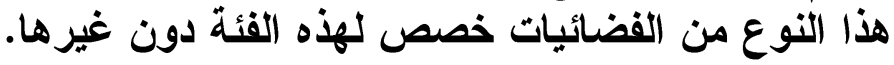

يشمل مجتمع الاراسة الأي تم اختيار العينة منه: عبنـة الأطفنال

جميع الفئات العمرية لمرحلة الطفولة المتأخرة التي تتراوح غالبًا ما بين ست

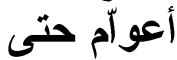

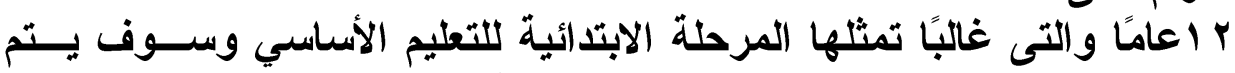

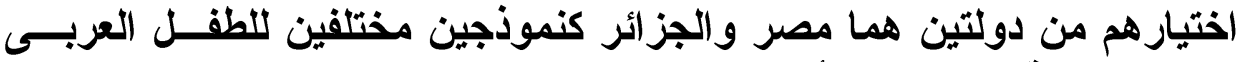

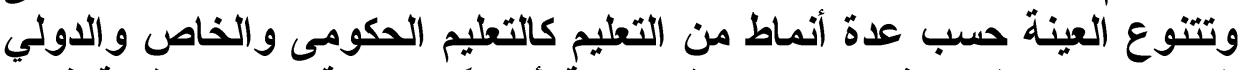

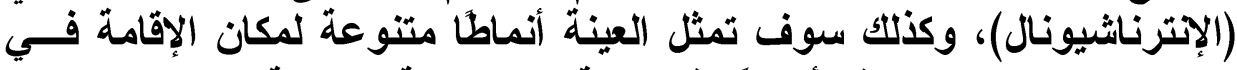

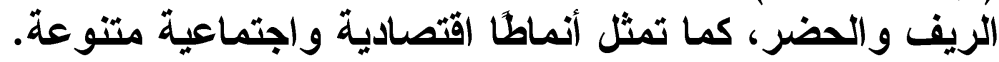
• اختيار عينة تمثل أنماطا متنوعة أيضًا من آباء الأطفال المبحوثئه مثين. 


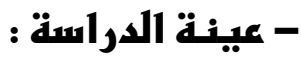

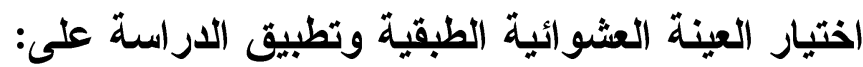

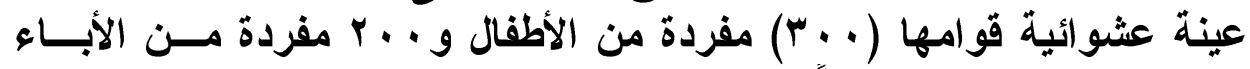

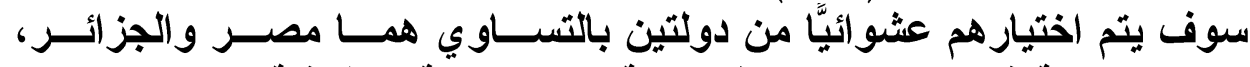

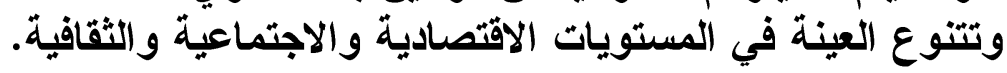

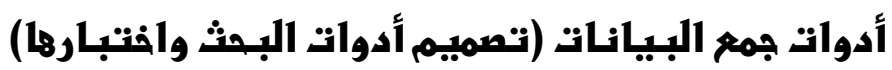

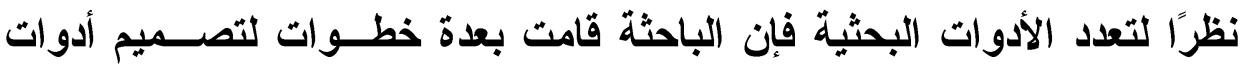

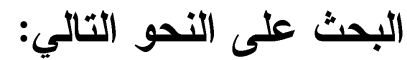
- تصميم أداة الار اسة الميدانية المئة للأطفال والآباء.

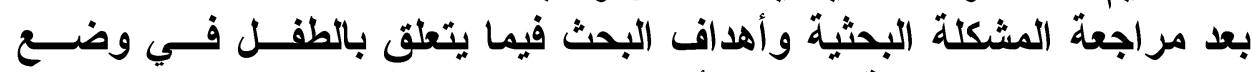

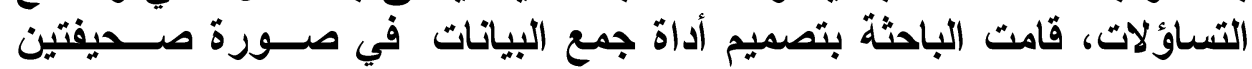

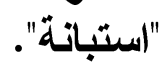

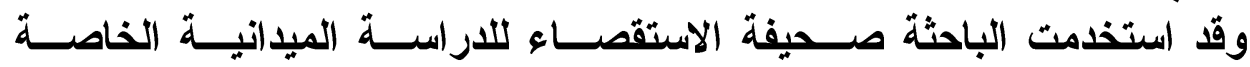

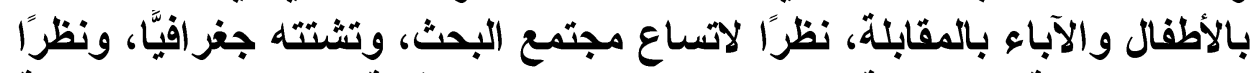

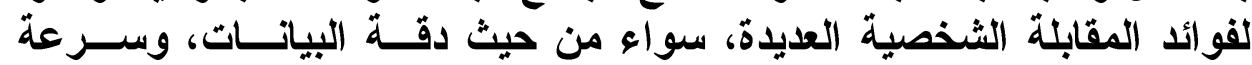

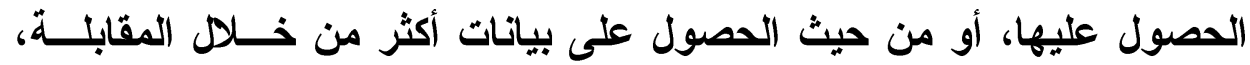
وحول طريقة الإجابة على الأسئلة. قباسر متغهيرات الدراسةة:

أ- كيف تم إعداد مقياس الوعي الصحي لادي الد الأطفال والآباء:

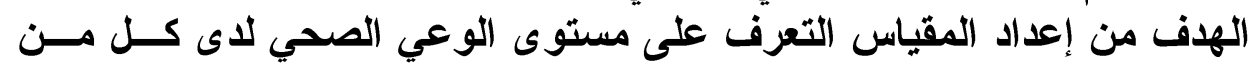

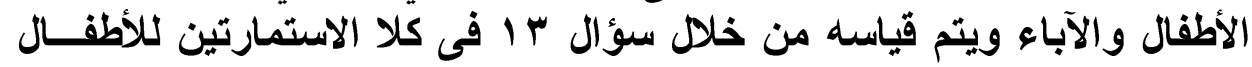
و الآباء.

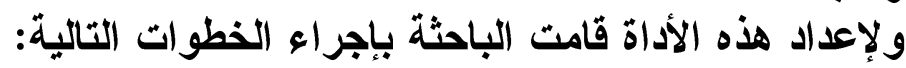

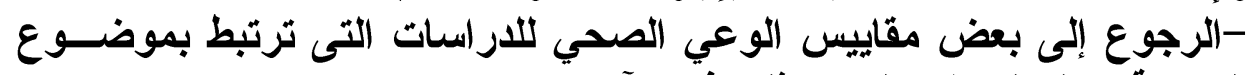

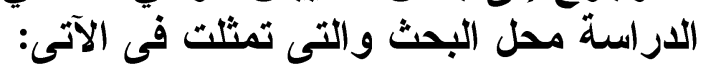

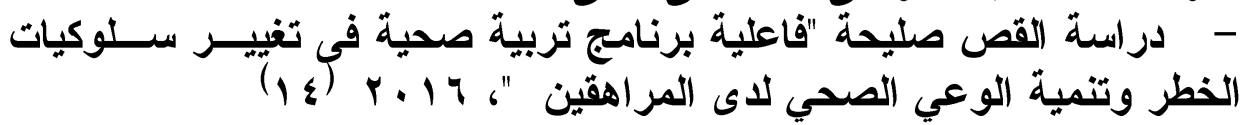

(ع () القص صليحة، فاعلية برنامج تربية صحية فى تغيير سلوكيات الخطر وتتمية الوعي

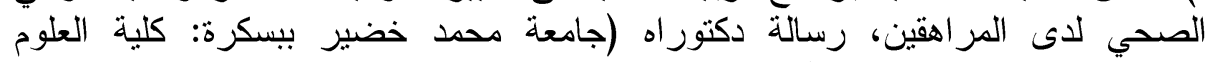

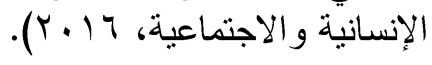


مجلة كلية الآداب، جامعة سوهاج، العدد الثالث والخمسون، الجزء الثاني، أكتوبر 19 • ب م

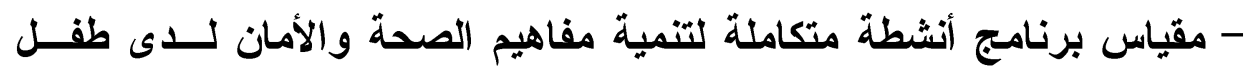

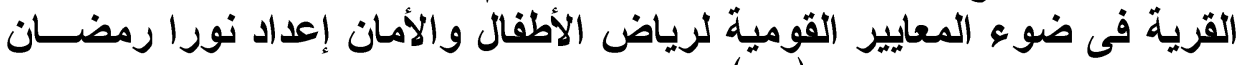

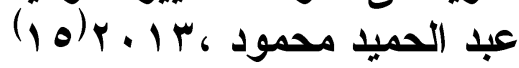

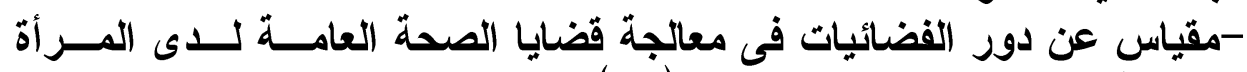

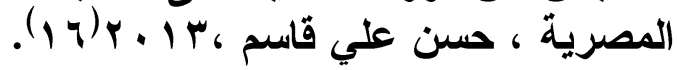

-مقياس فاعلية البرامج الصحية التليفزيونية فى تنمية الوعي الصحي لمعلمة

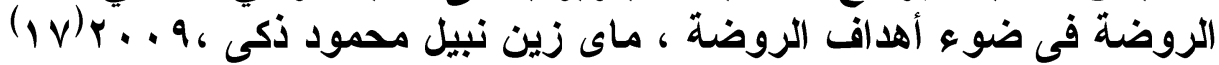

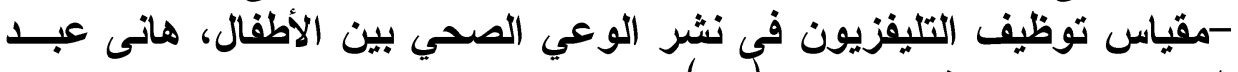

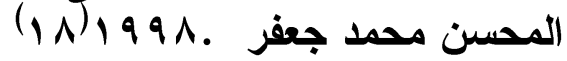

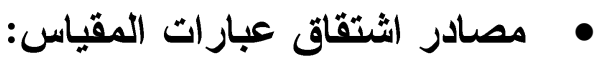
اعتمدت الباحثة فى اشتثاق عبار عات المقياس على عدة مصادر اشتثلث على:

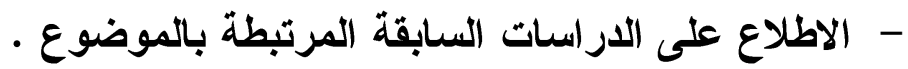

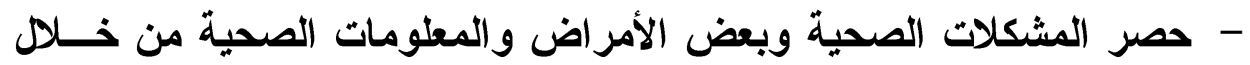
دراسة استطلاعية لعينة من الأطباء والأطفال والآباء .

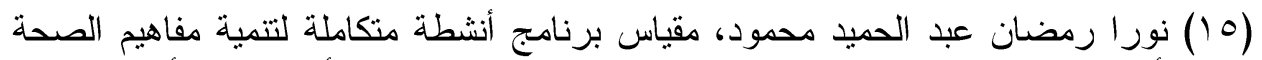

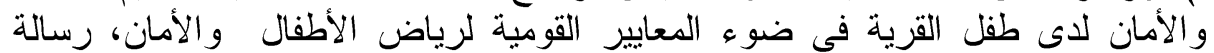

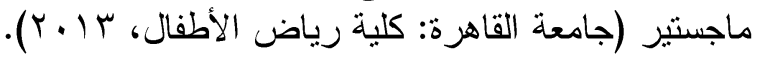

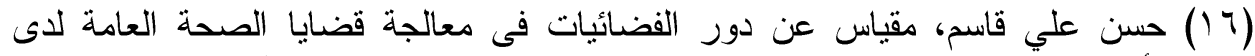

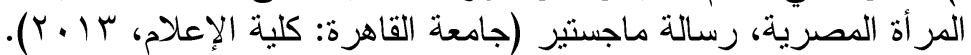

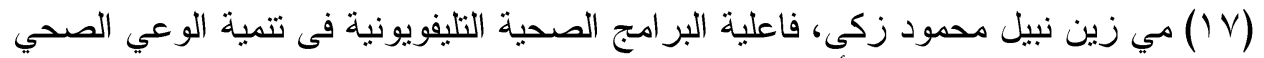

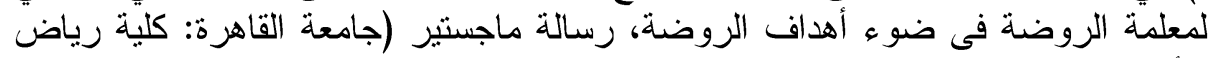

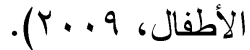

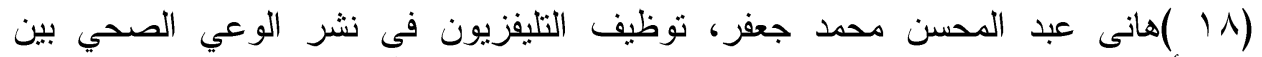
الأطفال، رسالة دكتور اه(جامعة القاهرة: كلية الإعلام، 991 ()). 


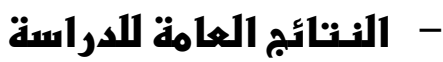

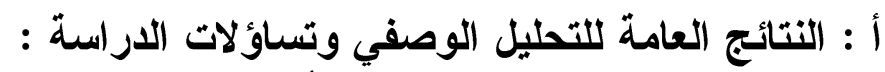

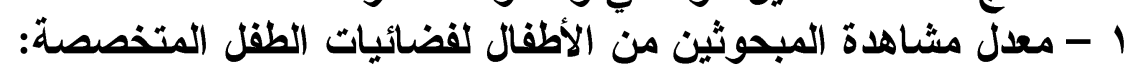

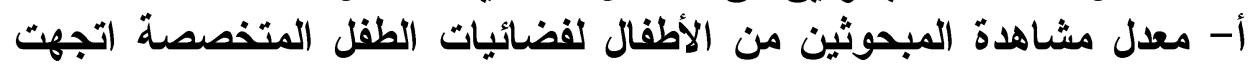

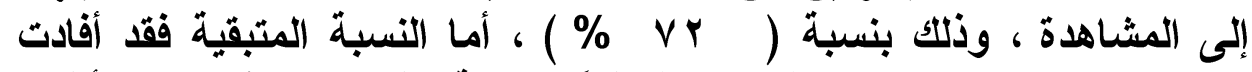

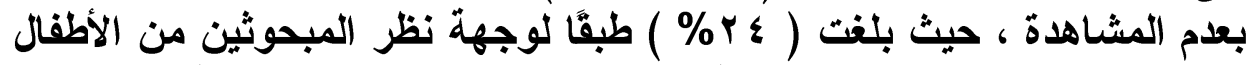

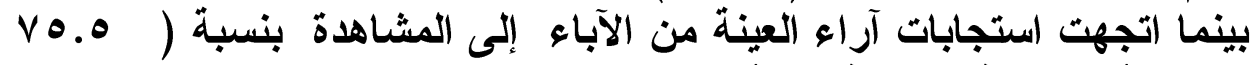

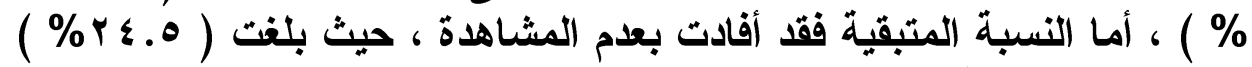
وهى نسب متقاربة لحد كبير. - مما يلنا على أن أغلبية عينة الاراسة تثاهد فضائيات الطفل

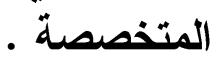

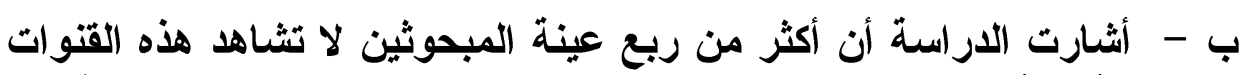

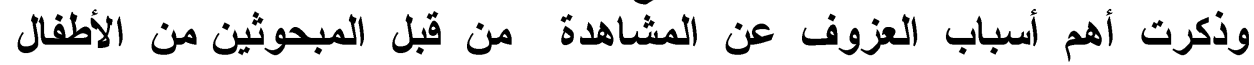

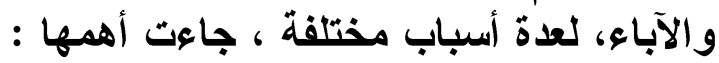

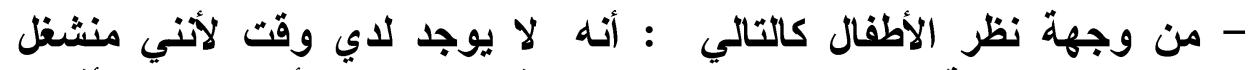

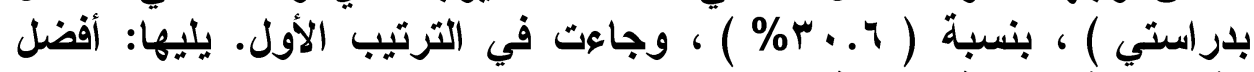

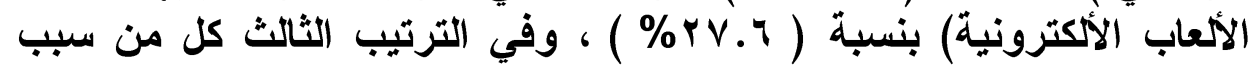

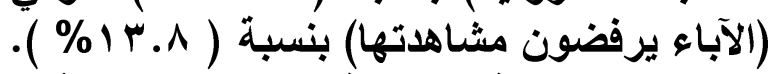

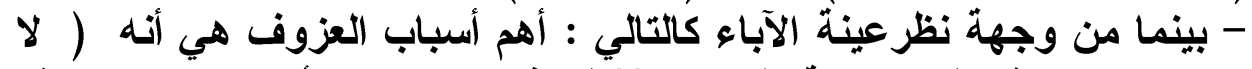

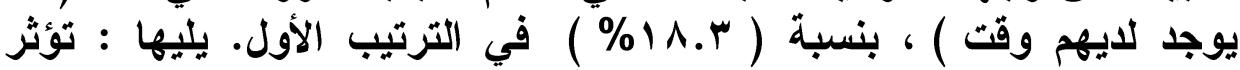

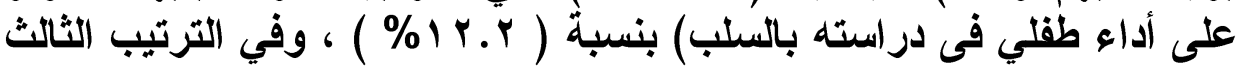

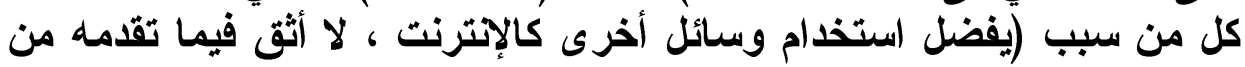

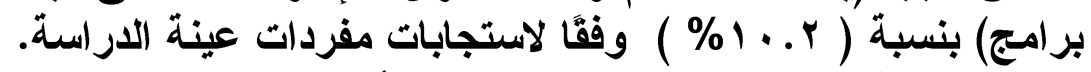

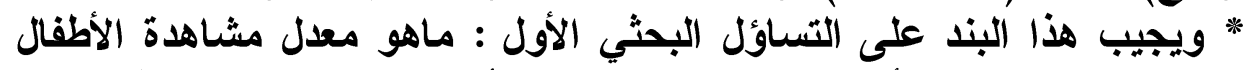
لفضائيات الطفل و أسباب عزوف بعض الأبفاول الطفال عن مشاهدة فضائيات

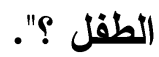
r - الفضائيات التي يحرص الطفل على مشاهداتها بانتظام.

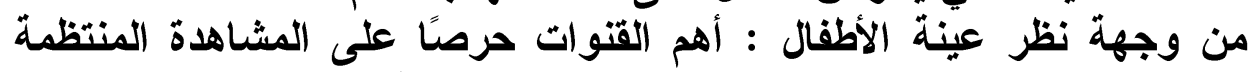

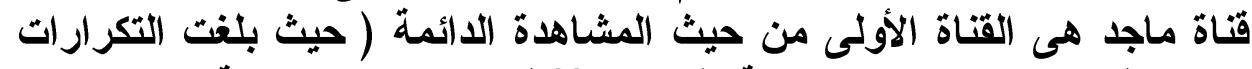

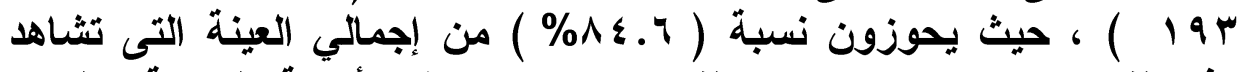
هذه الفضائيات ، وجاء ترتيب الفضائيات من حيث الأهمية النسبية والوزية تلونية

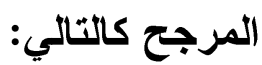




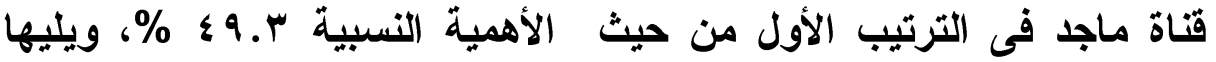

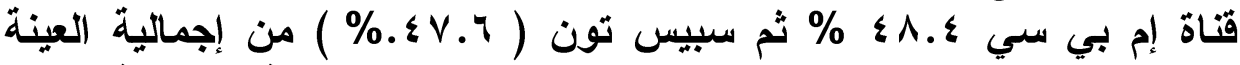

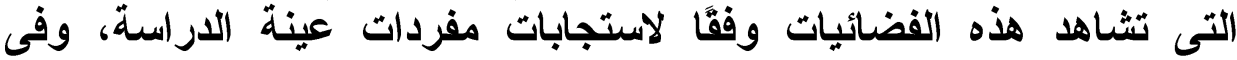

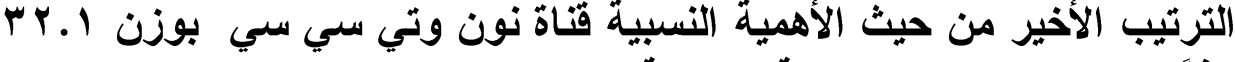

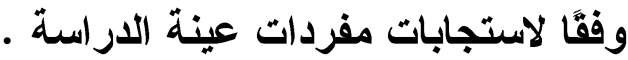

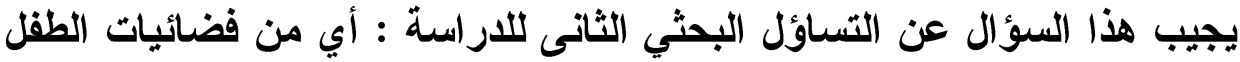

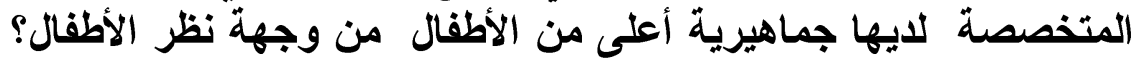

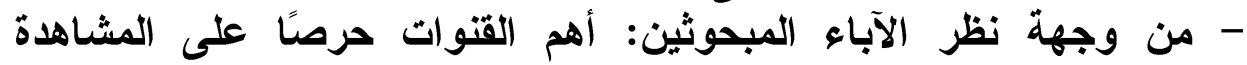

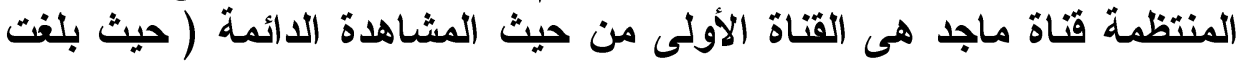

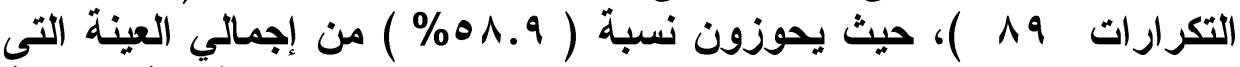

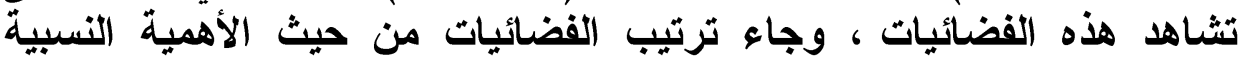
والوزن المرجح كالتالي:

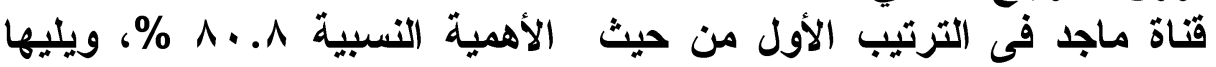

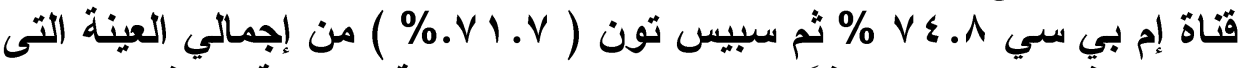

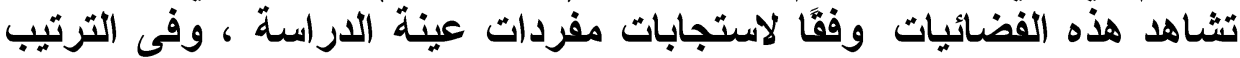

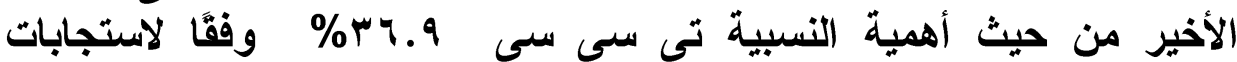
مفردات عينة الار استة. مما يجيب عن التساؤل البحثي الثالث للاراسة : أي من فضائة فئيات الطقل

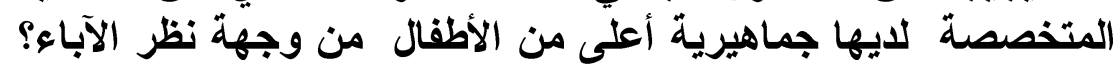

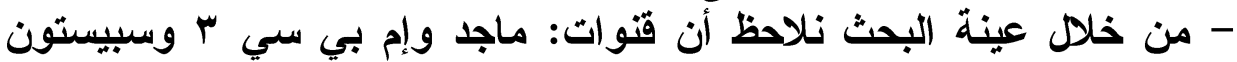

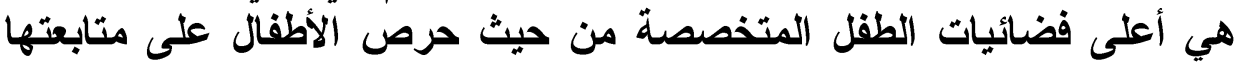
بانتظام من وجهة الأطفال و الآباء.

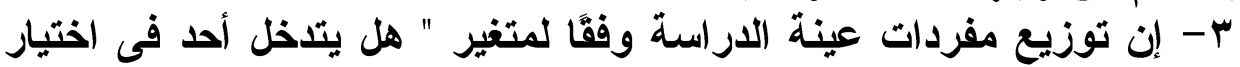
البرامج التي تثـاهدها.

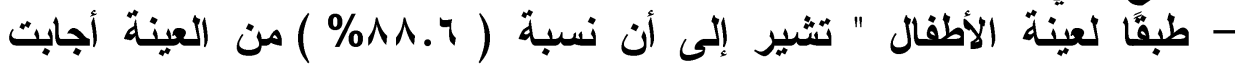

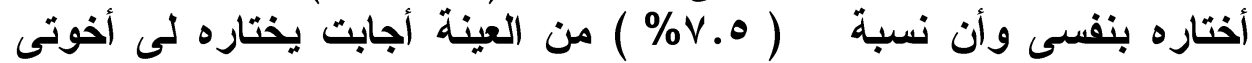

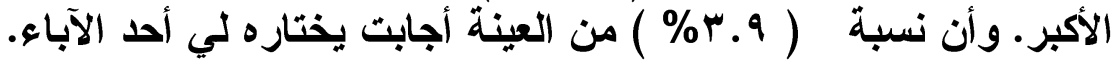

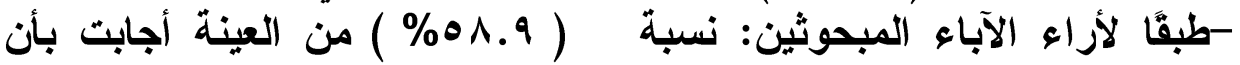

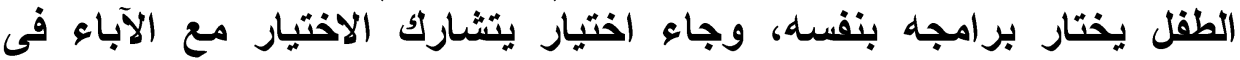

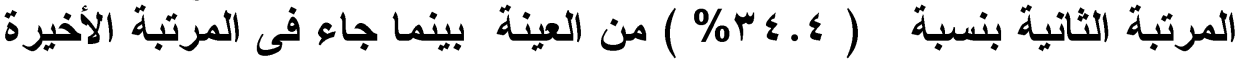

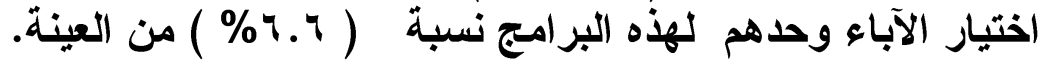

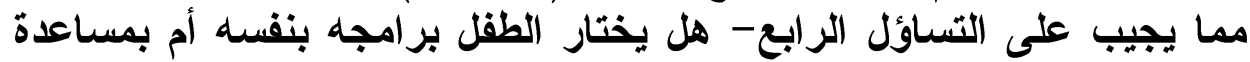
الآخرين من وجهة نظر الأطفال المبحوثين وآبائهج؟ 
؟- مصادر حصول كل من الآباء والأطفال فى الحصول على المعارف

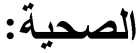
-بالنسبة لترتيب مصادر الأطفال أكثر المصادر للحصول على المعارف الصحية

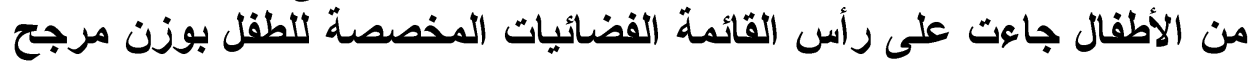

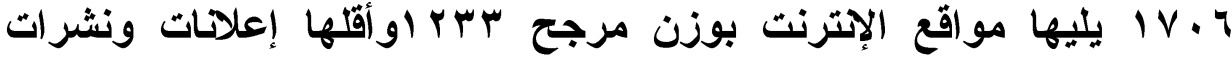

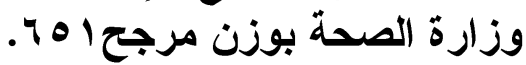

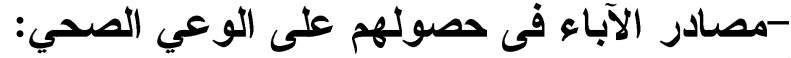

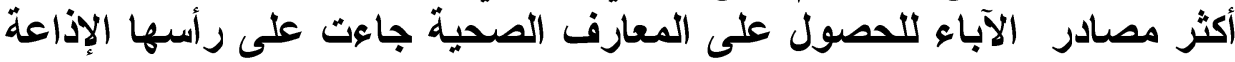

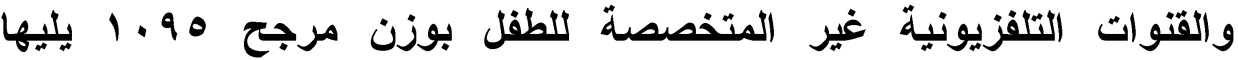

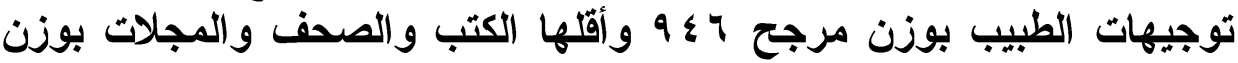

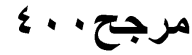

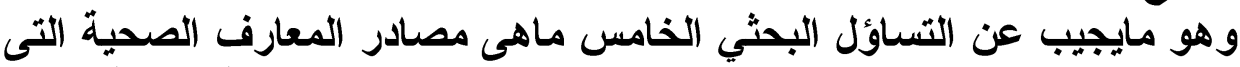
يعتمد عليها الأطفال والآباء فى ألحصول على المعلى ماهلومات الصحية الهامة للطفل

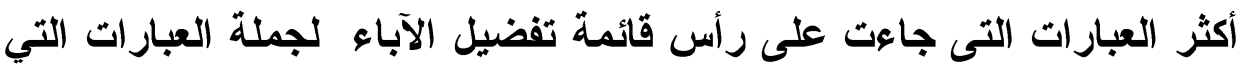

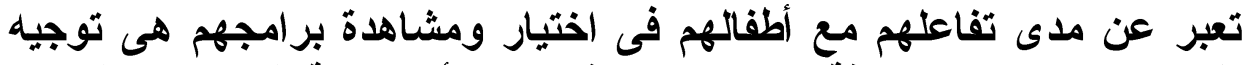

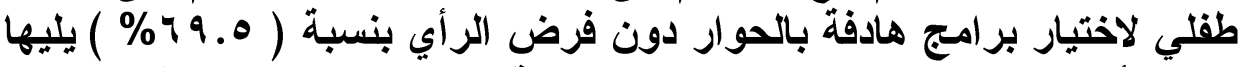

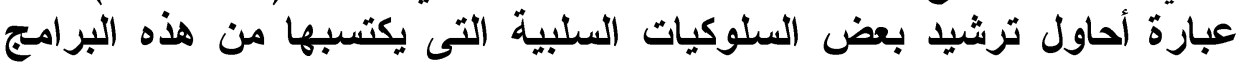

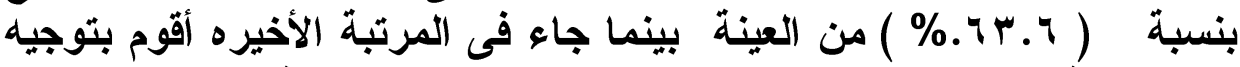

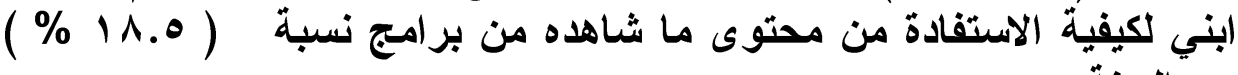

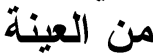
وهو ما يجيب على تساؤل الاراسة السادس ما مدى مشاركة وتفاعل آباء

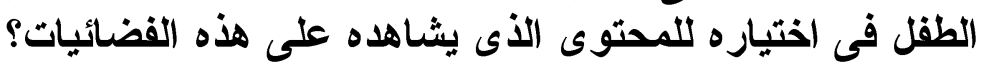

ع - من حيث تأثيرات الاعتماد على فضائيات الطفل للحصول على المعارف

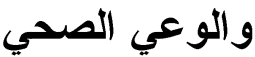
من وجهة نظر الأطفال -التأثيرات المعرفية نجد أن التأثيرات المعرفية للاعتماد على فضائيات الطقل

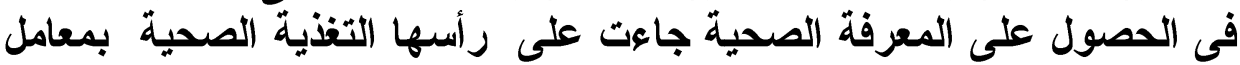

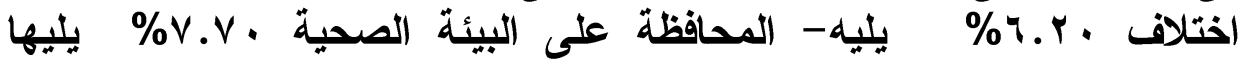

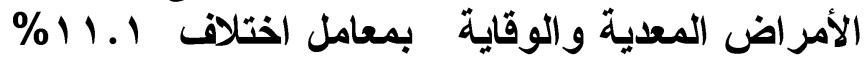

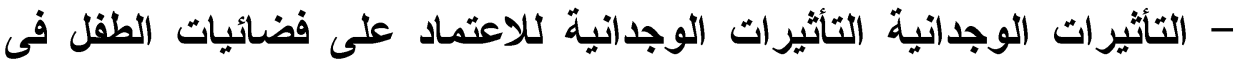

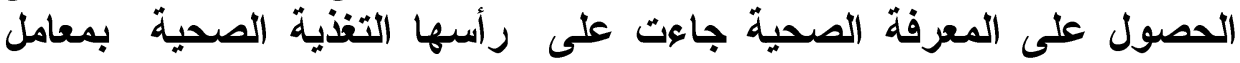




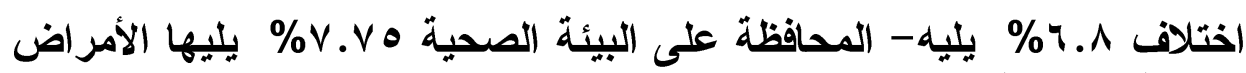

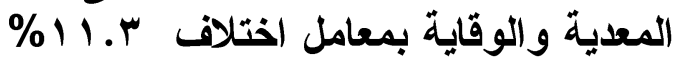

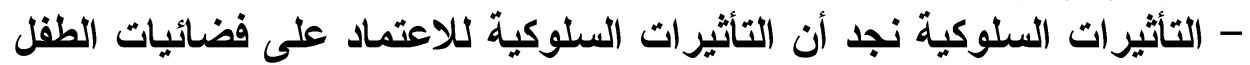

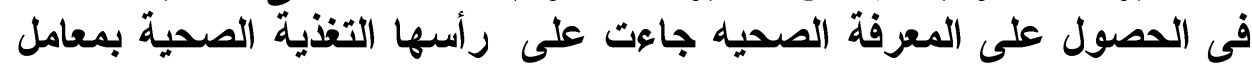

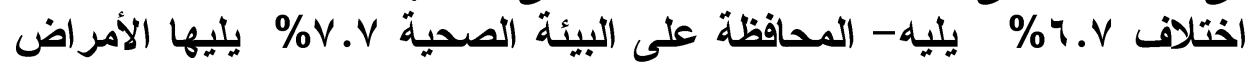

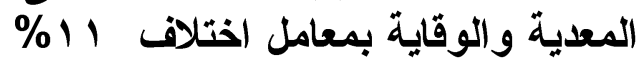

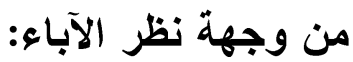
-التأثيرات المعرفية نجد أن التأثيرات المعرفية للاعتماد على فضائيات الطفل

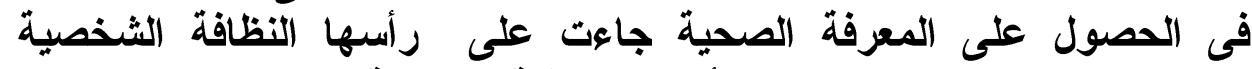

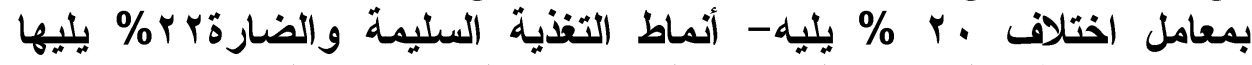
تعرف على أهمية ممارسة الرياضة والمحافظة على البيئة بمعامل اختلاف \% \% كليهما.

- التأثيرات الوجدانية نجد أن التأثيرات الوجدانية للاعتماد على فضائيات

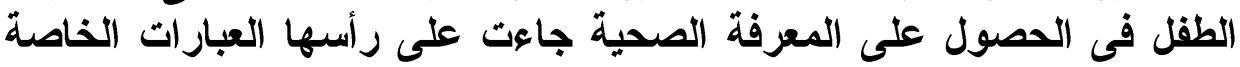

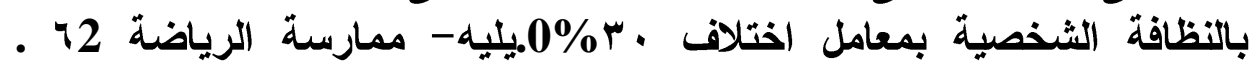

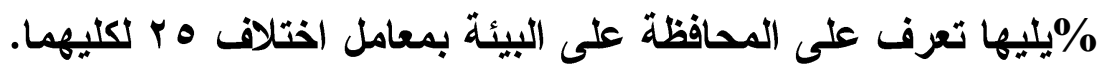

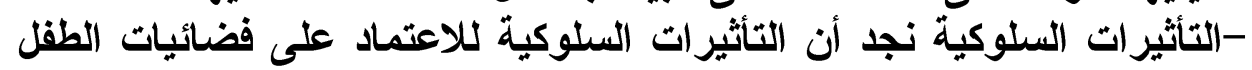

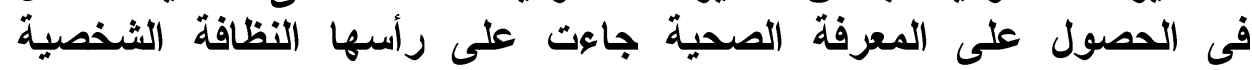

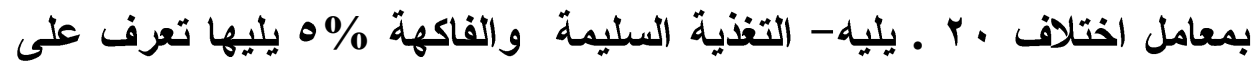

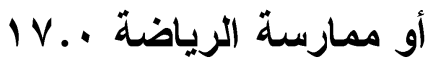

ماهم يجيب على التساؤل السابع إعائ. ماهى تأثيرات الاعتماد على فضائيات الطقل للحصول لعلى المعارف والوعي الصحي

צ- السلبيات التي يراها الأطفال والآباء فى قنوات الطقل المتخصصة:

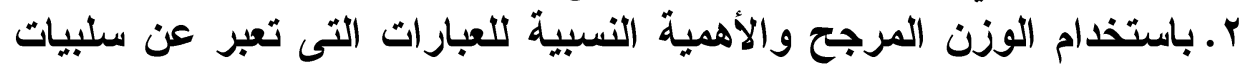

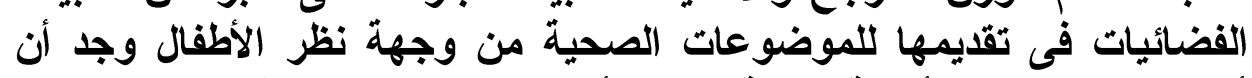

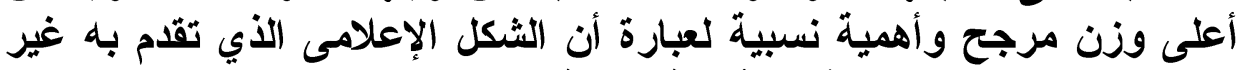

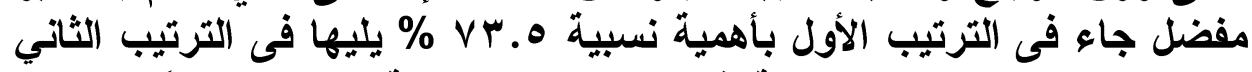

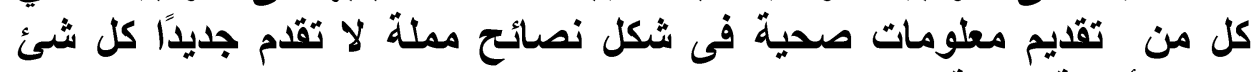

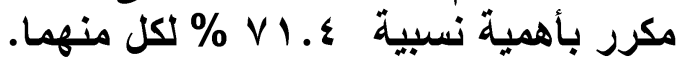

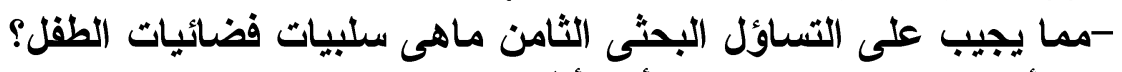
-V 


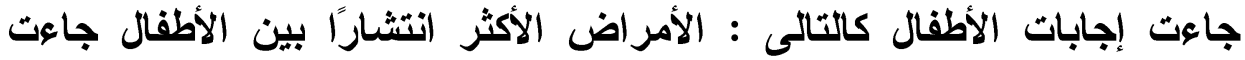

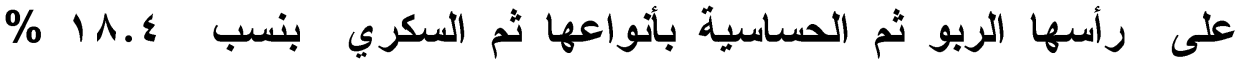

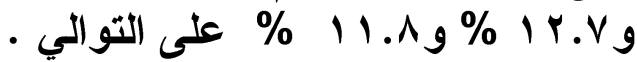

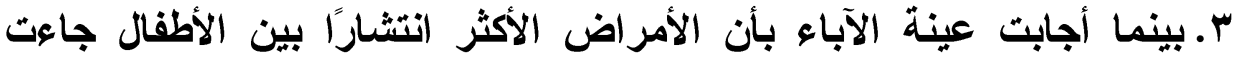

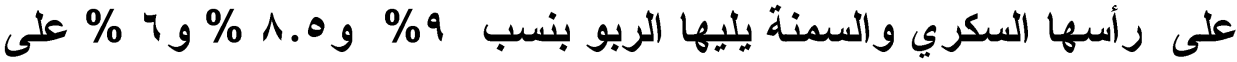

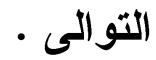

ع.وهو يجيب على تساؤل الاراسة التاسع ماهي أكثر الأمراض انتشارًا بين الأطفال فى كل من مصر والجز الائر ؟ 1-الاعتماد والاستفادة من مشاهدة فضائيات الطفل للحصول على المعارف

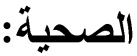

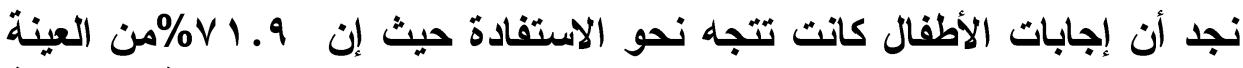

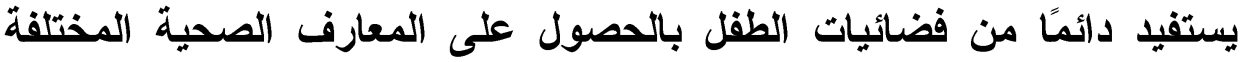

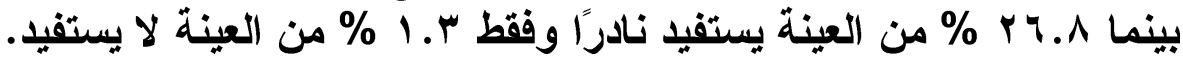

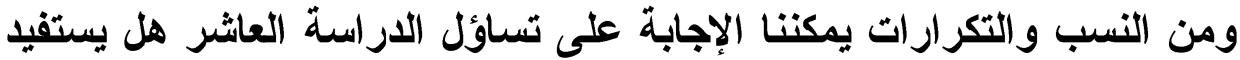

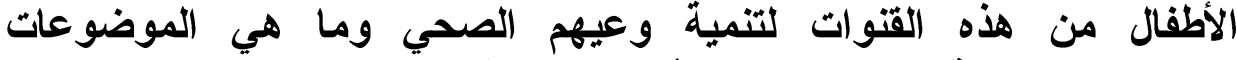
و المجالات الصحية التي استفادها الأطفال من هذه القئو القئوات ؟

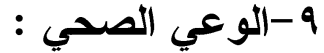

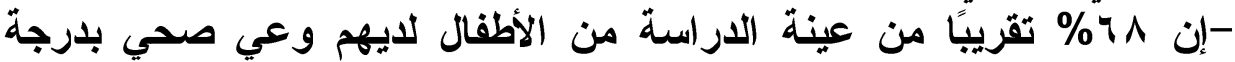

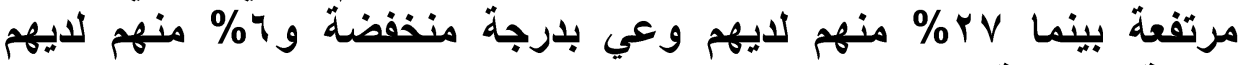

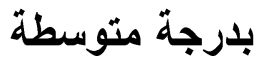

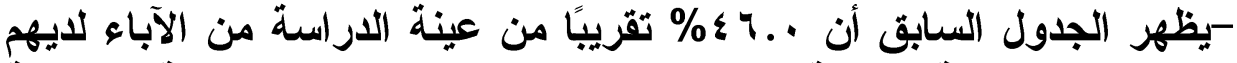

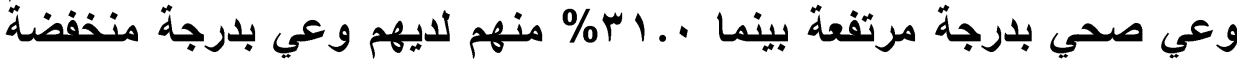

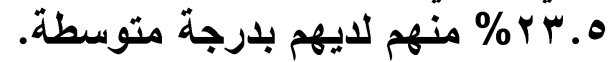

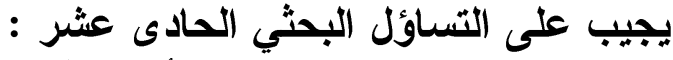

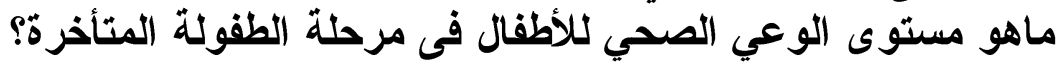

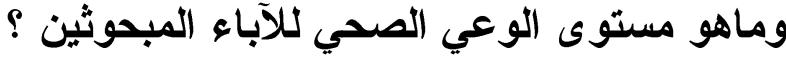

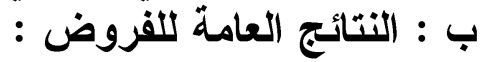
ال 1

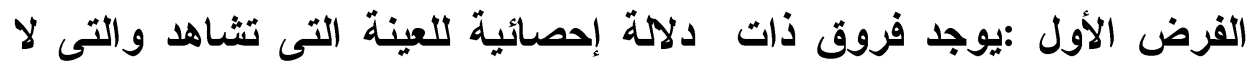

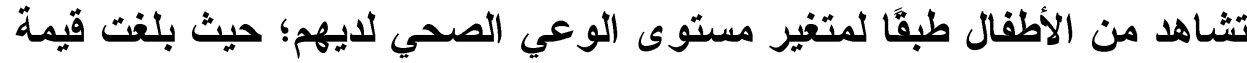

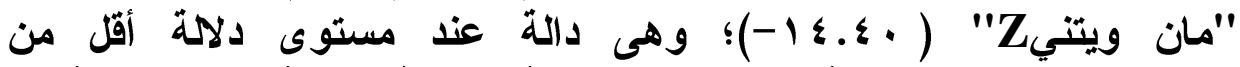

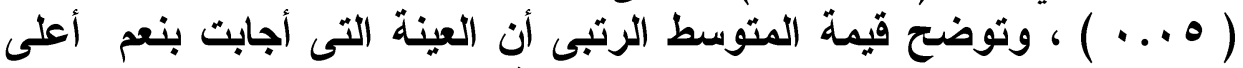

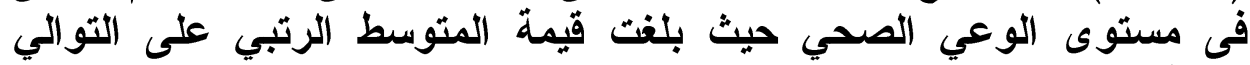

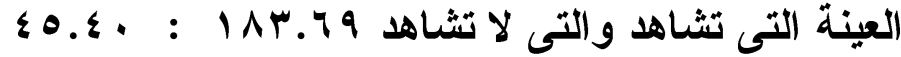


- بذلك نقبل الفرض الأول: يوجد فروق ذات دلالة إحصائية بين الوعي الصحي لاى الأطفال الأين يشاهدون والأين لا يشاهدون فضائيات الطفل دلان

الفرض الثانى : توجد علاقة طردية ذات دلاية إحصائية " بين اعتماد الطقل

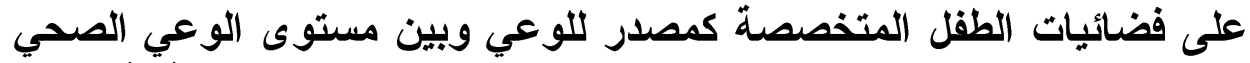

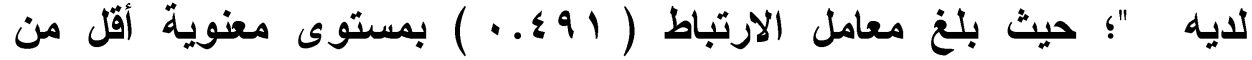

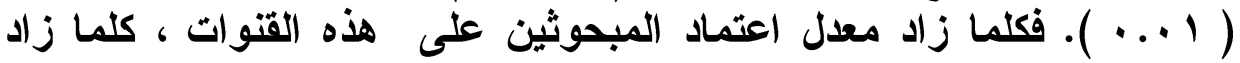
مستوى الوعي الصحي لايه.

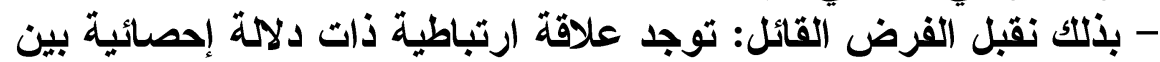

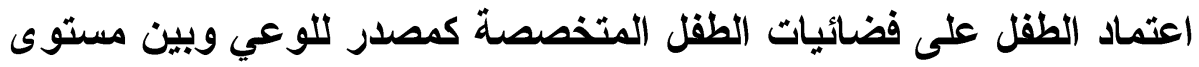
الوعي الصحي لايه. الفرض الثالث: - يوجد فروق ذايه ذات دلامة إحصائية لمتفير عينة المبحوثين

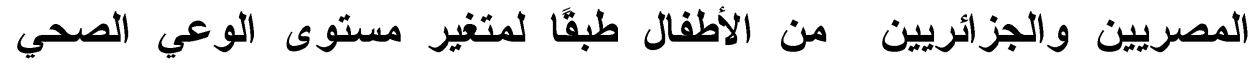

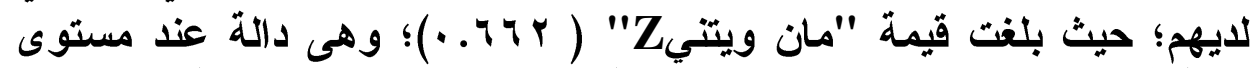

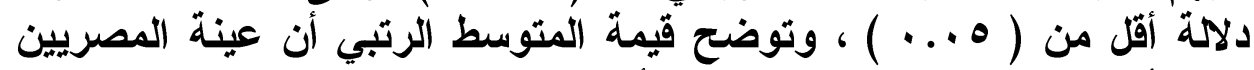

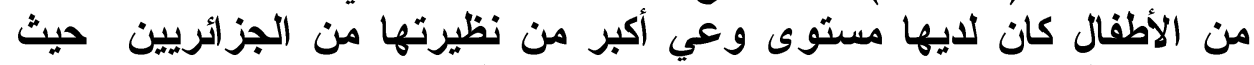

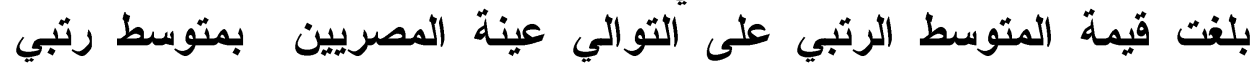

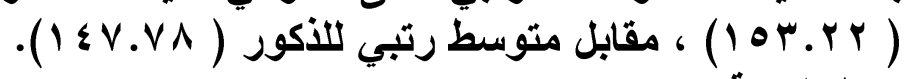
- الخلاصة :

بذلك نقبل الفرض : " توجد فروق ذات دلامة إحصائية بين مستوى الوعي الصحي لاي الأطفال المبحوثين من المصريين والأطفال المبحوثين الجزئ دائرينين. استمارة الأباء الاءل الأ

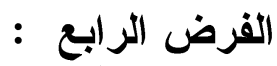
- يوجد فروق ذات لاتلة إحصائية لمتغير عينة المبحوثين المصريين

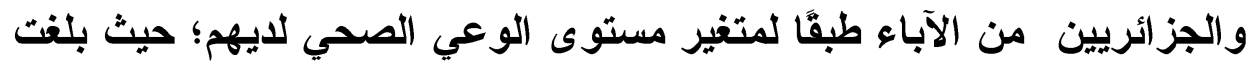

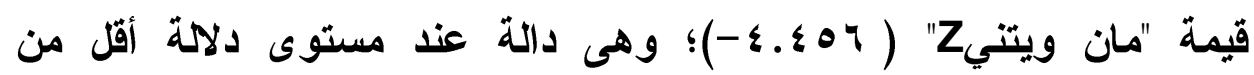

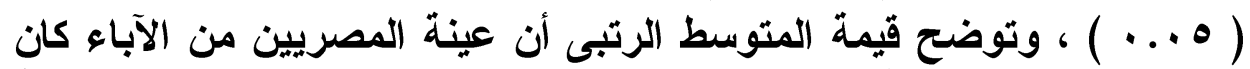

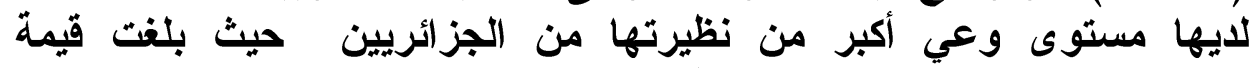

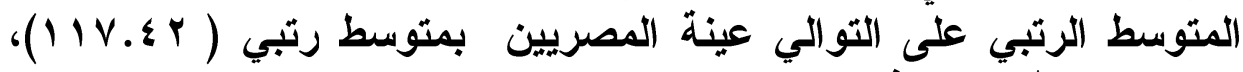
مقابل متوسط رتبي للأكور .$(\wedge r . \diamond \wedge)$ 


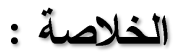

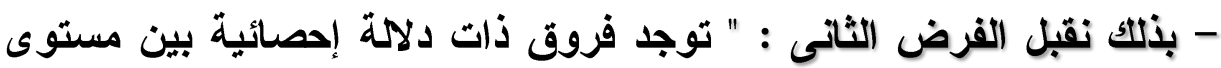

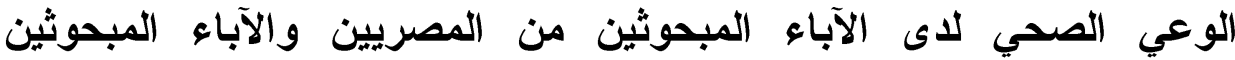

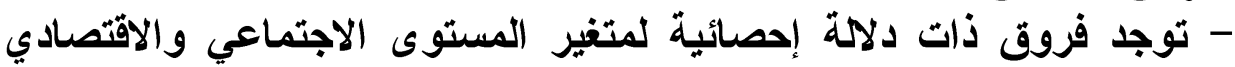

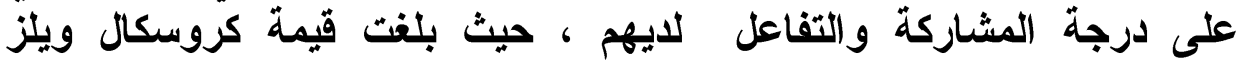

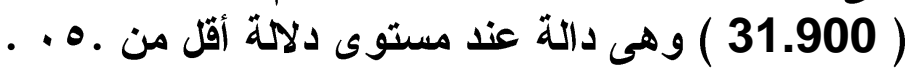

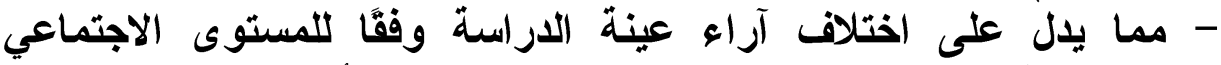

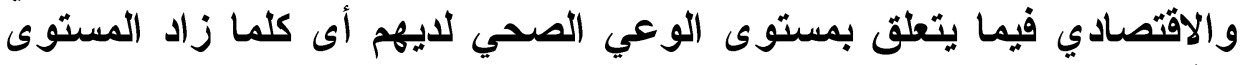
الاقتصادى والاجتماعى زاد الوعي الصحي للايهم والعكس.

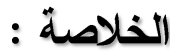

- بذلك نقبل الفرض الخامس في بعض أجزائه القائلة : " توجد فروق ذات

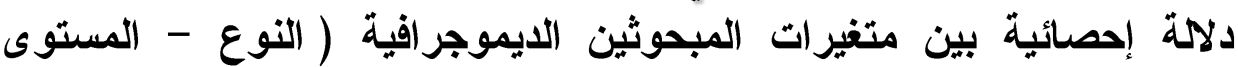

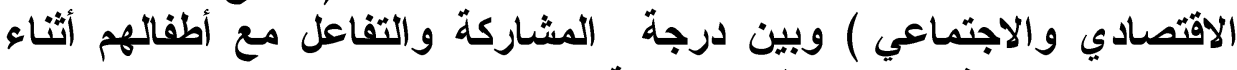
تعرضهم لبرامج فضائيات الطفل الصحية.

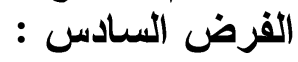
- يوجد فروق بين متغير عينة المبحوثين المصريين والجزائريين من الآباء

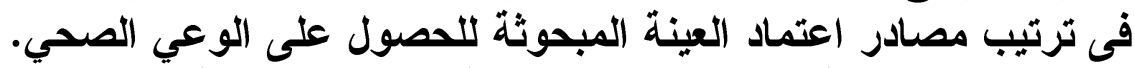

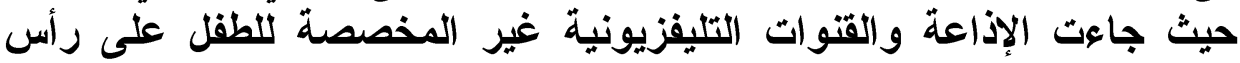

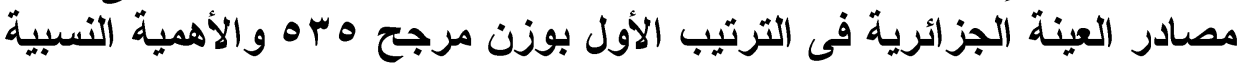

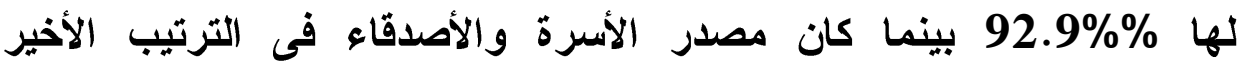

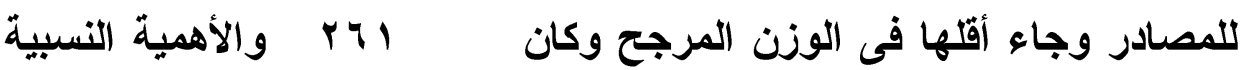
لها كاتت 45.3\% حيث جاعت توجيهات الطبيب على رأس مصادر العينة المصرية فى الترتيب

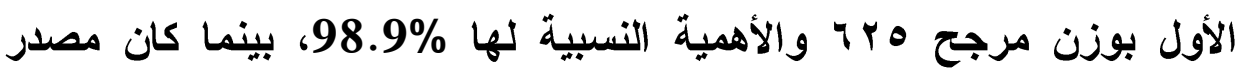
الكتب والصحف والمجلات فى الترتيب الأخير للمصادر وجاعت ألقاتها فى الوزن

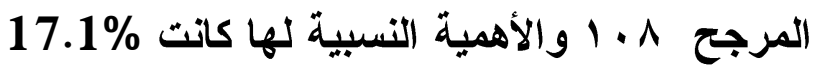


الفلاصة :

- بذلك نقبل الفرض السادس : " توجد فروق ذات دلامة إحصائية بين ترتيب

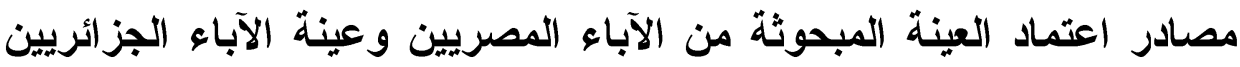
للحصول على الوعي الصحي.

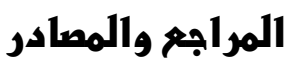

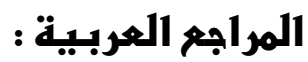

r- العرجان جعفر وذيب مرفت والكيلاتى غازى مستوى الوعي الوعي الصحي ومصادر الحصول على المعلومات الصحية لدى طلبة جامعة البلة البقاء

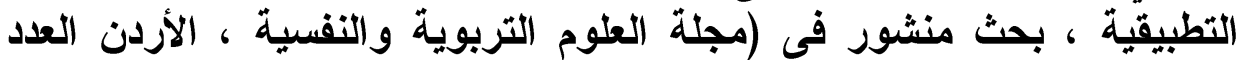

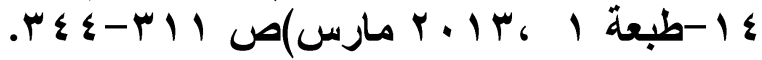

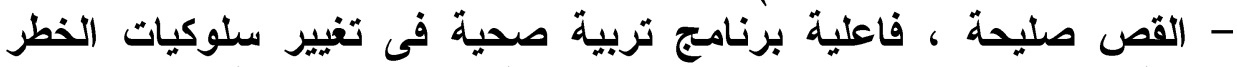

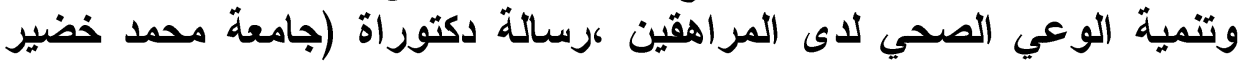

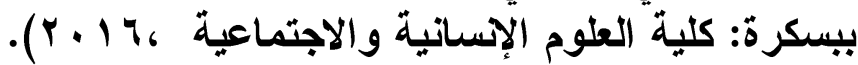

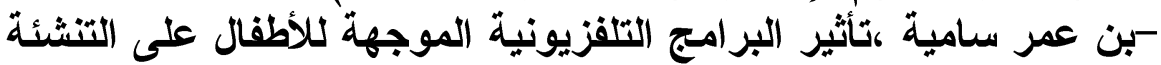

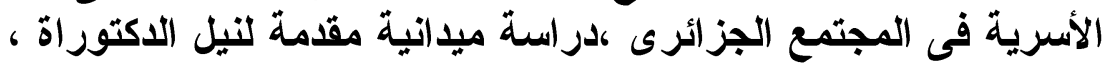

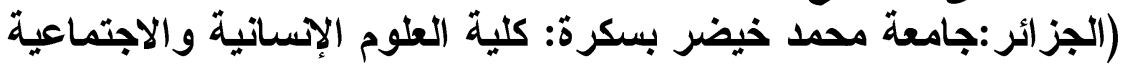
(r) -حسن على قاسم ، مقياس عن دور الفضائيات فى معالجة قضايا الصحة الصائ العامة لاى المرأة المصرية ، ، رسالة ماجستير (جامعة القاهرة: كلية الإعلام

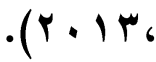

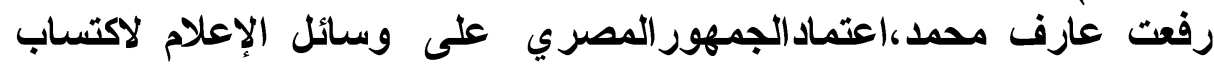

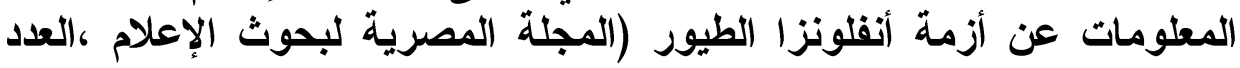

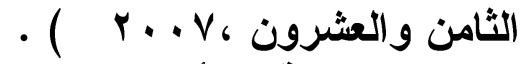

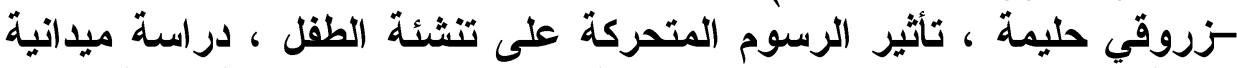

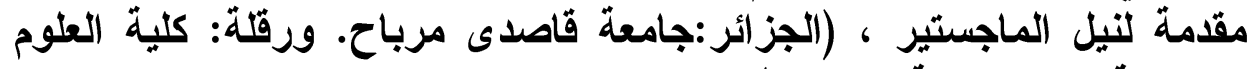

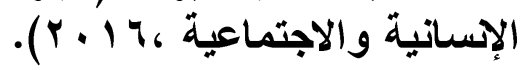

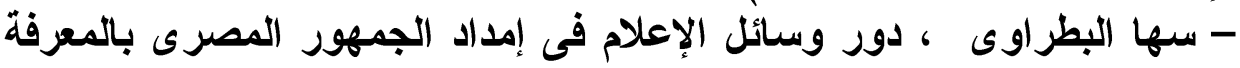

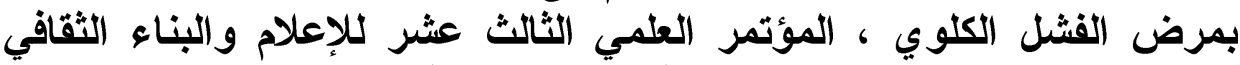

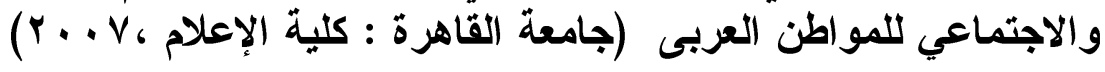

- عماد عبد المقصود شلبي ، علاقة التعرض للبرامج الصحية بالقنوات التبري

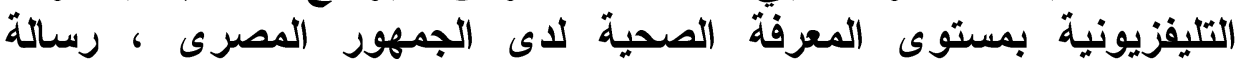
ماجستير غير منشورة (جامعة القاهرة : كلية الإعلام ، . . . r). 
- مي زين نبيل محمود زكى، فاعلية البرامج الصحية التلفزيونية فى تنمية

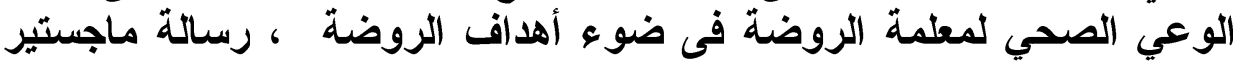

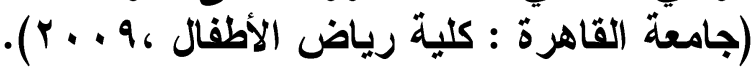

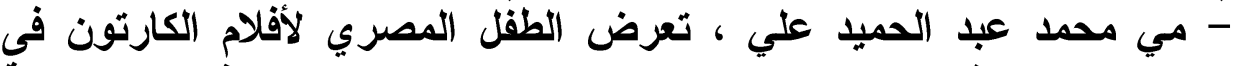

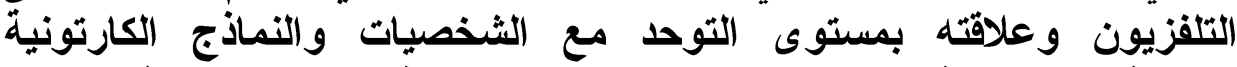
المقدمة " رسالة ماجستير غير منشورة (جامعة القاهرة : كلية الإعلام $\cdot\left(r \cdot 1 r_{6}\right.$ - - نورا رمضان عبد الحميد محمود ، مقياس برنامج أنشطة متكاملة لتنمية

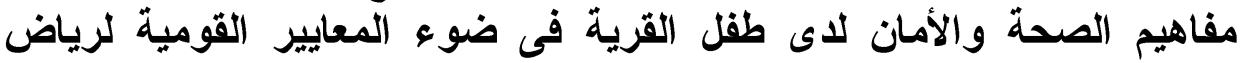

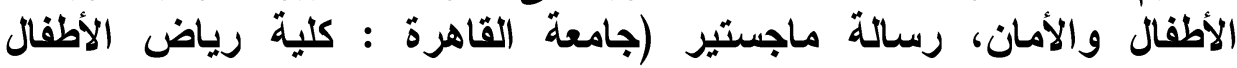

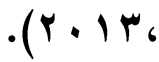

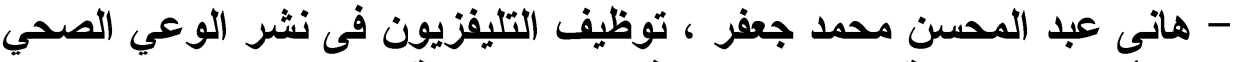

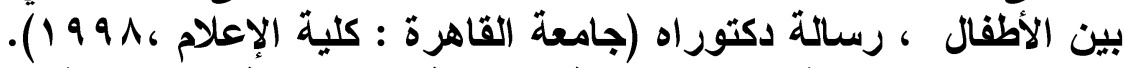

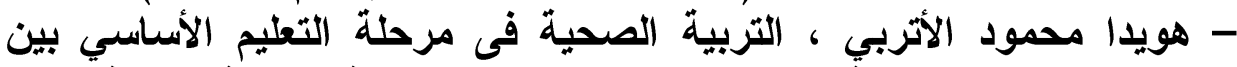

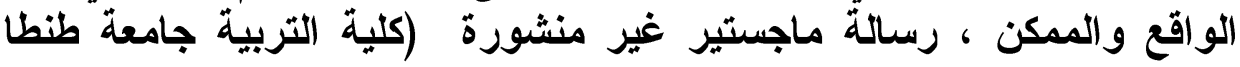

\section{نانباً: المصادر الأجنببة}

- Sandra ball. Rokeach :the Origins of Individual Media system dependency ,Asocial Framework, communication research ,(vol.12,no.4,October 1985)pp.485-488

- Viswanath.V.Breen.H.Moser.P.Richard .Bstede.W.Randoliph and R.william,cancer and disparities in the information age : (Journal of Healthcommunication, Vol .11,No 2006) pp1-19.

- Ye.Yinji Viswanath,v.breen, H. Moser, P.Richard, B.Stede, w. Randdolph. and R.William ao" The role of media health information in individuals subjective wellBeing:an Explloration of effects of portrayals of health risk in television news .medical dramas ,and pharmaceutical advertising Ph.D (usa :the university of Albama,2004) 